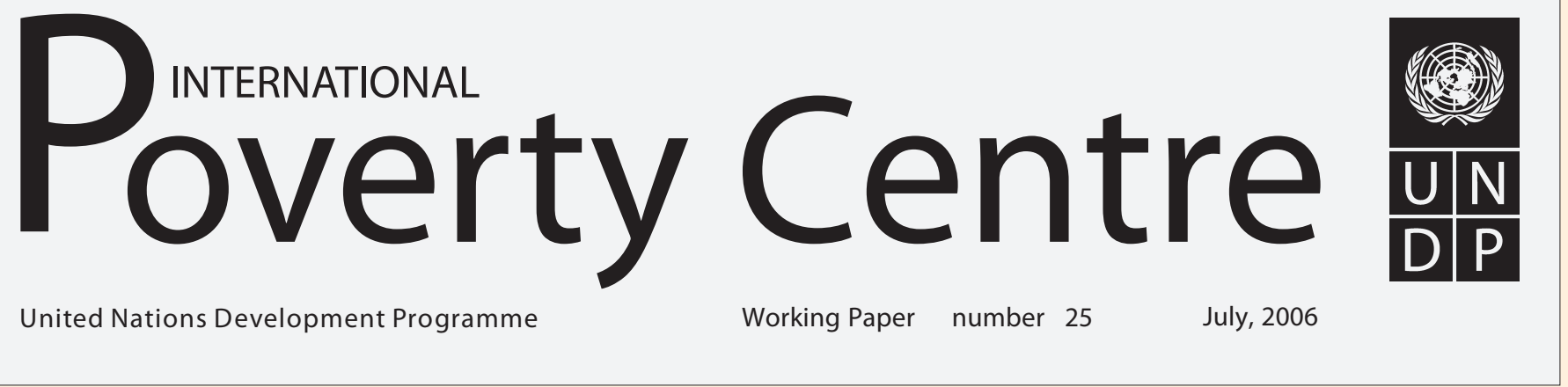

\title{
CHINESE POVERTY: ASSESSING THE IMPACT OF ALTERNATIVE ASSUMPTIONS
}

Sanjay G. Reddy

Dept. of Economics, Barnard College,

Columbia University

and

Camelia Minoiu

Dept. of Economics and Institute for Social and Economic Research and Policy, Columbia University 


\title{
Copyright $(2006$
}

United Nations Development Programme International Poverty Centre

\author{
International Poverty Centre \\ SBS - Ed. BNDES, $10^{\circ}$ andar \\ 70076900 Brasilia DF \\ Brazil \\ povertycentre@undp-povertycentre.org \\ www.undp.org/povertycentre \\ Telephone +55 6121055000 \\ Fax +556121055001
}

\section{Rights and Permissions}

All rights reserved.

The text and data in this publication may be reproduced as long as the source is cited.

Reproductions for commercial purposes are forbidden.

The International Poverty Centre's Working Papers disseminates the findings of work in progress to encourage the exchange of ideas about development issues. The papers are signed by the authors and should be cited and referred to accordingly. The findings, interpretations, and conclusions expressed in this paper are entirely those of the authors. They do not necessarily represent the views of the International Poverty Centre or the United Nations Development Programme, its Administrator, Directors, or the countries they represent.

Working Papers are available online at http://www.undp.org/povertycentre and subscriptions might be requested by email to povertycentre@undp-povertycentre.org 


\title{
CHINESE POVERTY: ASSESSING THE IMPACT OF ALTERNATIVE ASSUMPTIONS*
}

\author{
Sanjay G. Reddy ${ }^{* *}$ and Camelia Minoiu***
}

\begin{abstract}
This Working Paper investigates how estimates of the extent and trend of consumption poverty in China between 1990 and 2001 vary as a result of alternative plausible assumptions concerning the poverty line and estimated levels of consumption. The exercise is motivated by the existence of considerable uncertainty about the appropriate poverty lines to apply and the level and distribution of resources in China. Our methodology focuses on the following sources of variation: alternative purchasing power parity conversion factors (used to convert an international poverty line), alternative estimates of the level and distribution of private incomes, alternative estimates of the propensity to consume of lower income groups, and alternative consumer price indices. It is widely believed that substantial poverty reduction took place in China in the 1990s, and we find this conclusion to be robust to the choice of assumptions. Moreover, there is no evidence that the rate of poverty reduction declined over time. China's record of reducing consumption poverty has been dramatic. However, estimates of the extent of Chinese poverty in any year are greatly influenced by the assumptions made. The choice among these estimates is likely to have large implications for the perceived extent and trend of world poverty.
\end{abstract}

Keywords: Consumption poverty, China, Sensitivity analysis.

JEL Classification: 132, D31

\footnotetext{
* This Working Paper has been made possible by support from the Bureau of Development Policy and the International Poverty Center of the United Nations Development Programme. We want to thank Terry McKinley, Director of the International Poverty Centre, for facilitating this support and for his comments on the paper. We would like especially to thank Shaohua Chen, Yan Fang, Azizur Rahman Khan, Albert Park, Martin Ravallion, and Li Shi for their assistance with queries; Carl Riskin and seminar participants at Columbia University for their helpful comments; and Prabhjot Kaur for her research assistance. Updates of this paper can be found on <www.columbia.edu/ sr793/china.pdf $>$.

** Dept. of Economics, Barnard College, Columbia University.

Email: sr793@columbia.edu. Tel. 212-854-3790, Fax.212-854-8947.

${ }^{* * *}$ Dept. of Economics and Institute for Social and Economic Research and Policy, Columbia University. Email:cm2036@columbia.edu.
} 


\section{INTRODUCTION}

The extent and trend of poverty in China play a crucial role in determining the extent and trend of poverty in the world. ${ }^{1}$ However, there is substantial uncertainty concerning Chinese poverty, despite recent studies on the topic. Some of these uncertainties are data-related (for example, nationally representative household surveys are not publicly available for China, and poverty analysis must be undertaken on tabulated data that is disaggregated by rural and urban area -- see e.g., Chen and Ravallion (2001a, 2001b, 2004, 2005) and Chen and Yang (2001)), while others relate to methodology (for example, there is no 'official' national poverty line for China). This Working Paper contributes to the literature by presenting the first set of national consumption poverty estimates for China covering a series of recent years and based on alternative plausible assumptions concerning poverty lines and other parameters.

In this Working Paper, we present consumption poverty estimates for China for selected years between 1990 and 2001 based on alternative choices of poverty lines and assumptions concerning the consumption profile (i.e., the distribution of absolute consumption levels) in each year. From the outset, it should be noted that our aim is not to present a new set of point estimates of poverty for China and to claim these to be authoritative. That task is presently beyond the capabilities of non-official researchers due to data limitations. Rather, the aim of the paper is to present a set of poverty estimates based on alternative plausible assumptions concerning poverty lines and average consumption levels. As a result, we are able to come to the conclusion that the estimated trend of poverty reduction in China in the 1990s is strong regardless of the assumptions made. The alternative assumptions that we consider reflect judgments that have been made in other contributions to the literature.

In contrast to this study, other existing studies focus on only one set of possible assumptions. For example, Chen and Ravallion (2005) and Sala-i-Martin (2002a, 2002b, 2006) produce estimates of household income (rather than consumption) poverty. While Chen and Ravallion (2005) use survey-based average incomes for income quantiles, Sala-i-Martin (2002a, $2002 \mathrm{~b}, 2006)$ takes the view that the national accounts provide a more appropriate estimate of average household income. Furthermore, these studies (also including, e.g., Chen and Wang (2001)) use either a national consumer price index (CPI) covering a broad range of consumer goods or separate sectoral (rural and urban) consumer price indices covering a broad range of consumer goods to determine the level of the poverty line in each year. However, an 'adjusted CPI' that better reflects the prices of the commodities necessary to achieve basic human requirements, and thereby avoid poverty, might be thought more appropriate to employ in poverty assessments. While Khan and Riskin (2001) and Khan (2004) describe trends in rural and urban poverty using adjusted consumer price indices, their analysis is not undertaken at the national level and is limited to two years (1988 and 1995) and three years, respectively (1988, 1995 and 2002).

Due to the lack of publicly available household survey data for China that are both nationally representative and available for diverse years (see, for example, Khan and Riskin (2001) in the absence of such data for China), ${ }^{2}$ previous studies have either focused only on selected years or used tabulated data of income or consumption shares (derived from underlying household surveys that are unavailable to researchers). In this paper, we use publicly available tabulated data concerning income shares by decile (provided by the World Bank, which merged underlying national rural and urban household surveys for the years 1990, 
1992 to 1998 , and 2001 to produce the tabulated data). We use these income shares to arrive at a national consumption profile (and consequent consumption poverty estimates) based on a methodology discussed in detail below.

The methodology used in this paper to estimate Chinese national consumption poverty from the available data can be summarized in three steps:

First, we estimate a consumption profile from income shares. We identify alternative plausible estimates of per capita private income and transform income shares into an income profile (a distribution of absolute income levels corresponding to income groups). We then use alternative plausible estimates of consumption-to-income ratios to transform the income profile into a consumption profile. We express the consumption profile in a base year's (1993) prices using alternative consumer price indices.

Second, we identify poverty lines expressed in currency units of a base year. We wish to identify alternative poverty lines that span a plausible range that accommodate poverty lines proposed by official sources and experts in the literature on Chinese poverty. As a secondary goal, we also wish to ensure notional comparability between the poverty estimates we arrive at for China and poverty estimates for other countries. Accordingly, we ensure that the poverty lines we choose within a plausible span can be interpreted as corresponding to the international consumption poverty lines used by the World Bank and other analysts. We translate these poverty lines into currency values in different years using alternative consumer price indices including ones focused on the commodities needed to avoid poverty.

Third, we estimate the poverty headcount ratio using the alternative poverty lines and estimated consumption profiles for each available year using Lorenz curve interpolation techniques.

The lack of publicly available Chinese consumption profiles for multiple years precludes a direct analysis of household level data. While the consumption profiles must be estimated in an indirect manner, our methodology has the advantage of enabling us to investigate the impact of variation in several crucial assumptions concerning the estimated consumption profile in each year and the appropriate criteria for identifying the poor. These key parameters are: (a) alternative choices of the poverty line deemed plausible for China (while maintaining notional comparability with poverty estimates elsewhere in the world), (b) alternative estimates of the level and distribution of private incomes, (c) alternative estimates of the propensity to consume of lower income groups, and (d) alternative consumer price indices.

For notational purposes, we express each alternative set of consumption poverty estimates as corresponding to a vector of four parameters given by:

$$
\lfloor P L, \hat{Y}, \theta, \pi\rfloor
$$

where $P L$ refers to the poverty line chosen; $\hat{Y}$ refers to the estimate of per capita private income, $\theta$ refers to the estimate of the fraction of per capita private income devoted to the consumption of each income group, and $\pi$ is the consumer price index used to express consumption levels (or, alternatively, poverty lines) in constant prices.

To estimate poverty headcount ratios based on the data that are available to us, we use the World Bank's POVCAL software, which undertakes parametric curve fitting to interpolate 
a Lorenz curve. ${ }^{3}$ We test the accuracy of poverty estimates produced by the software by comparing the headcount ratios computed directly from a full household survey for China in 1995 against those based on applying POVCAL to consumption averages for deciles from the same survey (for details, see Appendix 2). The results give us some confidence that the parametric procedures for the estimation of the Lorenz curve produce poverty estimates which are relatively close to their survey counterparts, and we proceed to compute poverty headcount ratios with POVCAL in this paper.

The remainder of the Working Paper is structured as follows. Section II contains a review of the literature on income and consumption poverty in China. Section III presents the data used in the paper. Section IV discusses the alternative assumptions under consideration, introduces alternative poverty lines and discusses different estimates of per capita private consumption. It also presents consumption profiles based on refinements such as decilespecific consumption to income ratios and 'adjusted' inflation rates. Section $V$ constructs consumption profiles for China, and shows how estimates of the extent and trend of poverty vary with our assumptions about underlying parameters. Section VI presents our conclusions.

\section{RELATED LITERATURE}

A large literature has produced poverty estimates both for China and for the (developing) world. We review here recent literature on the extent and trend of poverty in China, some of it deriving from broader studies on the entire developing world. The literature on Chinese poverty often covers only a specific year and frequently only a specific sector (rural or urban China). Where studies cover multiple years, they are based on a single set of (frequently nontransparent) assumptions. A critical assessment of the uncertainties associated with poverty estimates for China can be found in Riskin (2004). A critical assessment of the uncertainties associated with poverty estimates for the developing world as a whole can be found in Reddy and Pogge (2006).

China's National Bureau of Statistics (NSB) reports only rural poverty estimates (NSB, 2004). (See Table 1.2 in Appendix 1.) Official estimates indicate that the number of rural poor dropped from 250 million (headcount rate of 30.7 per cent) in 1978 to 125 million (14.8 per cent) in 1985. This has been widely considered to be the most successful era of poverty reduction in China's history (Wang and Ren, 2004). During the 1990s, almost two thirds of the rural population was lifted out of poverty, with the number of poor falling from 85 million in 1990 to 32.1 million in 2000. A possible reversal of the trend of poverty reduction was encountered between 2002 and 2003 when rural poverty rose three per cent according to official estimates, despite GDP growth of eight percent.

These estimates are based on a national poverty line derived from China's representative rural household survey using an assumed minimum food energy intake requirement of 2,400 $\mathrm{kcal} /$ day (1984-1997) and 2,100 kcal/day (1998 to date) and a non-food expenditure estimate for basic necessities (Park and Wang, 2001). The poverty line was 206 Yuan in 1985, 300 Yuan in 1990, and reached 637 Yuan in 2003 (approximately \$0.75/day at the 1993 PPP for consumption applied by the World Bank). A new poverty line that is meant "to reflect the steadily improving living standards of rural households"4 (NBS, 2004) was set up in 2000 based on a 60 percent share of food in household consumption. This line is known as the 'lower income line' and represented 882 Yuan in 2003 (approximately \$1 per day at the 1993 PPP for consumption 
applied by the World Bank). The poverty headcount rate based on this higher poverty line was 9.1 percent in 2003, representing 85.2 million rural inhabitants. The methodology used to construct these poverty lines has not been made very transparent.

Yao (2000) contends that more than 200 million people in China were lifted out of poverty between 1978 and 1995 - greater than the poverty reduction implied by government statistics. The discrepancy is driven mainly by a large understatement of poverty in 1978 by the government. The paper argues that the poverty headcount ratio fell from 75.5-100 percent (596-790 million people) to 6.7-13.2 percent (57-114 million) over the period 1978-1996.

Park and Wang (2001) study sources of bias in the official rural poverty statistics. They allege that the official figures heavily underestimate rural poverty, while the pace of poverty reduction is grossly overestimated. Official statistics indicate a reduction in rural poverty headcount ratios of 27 percentage points between 1978 and in 2000. The authors argue that increases in the rural cost of living are inadequately accounted for, due to insufficient efforts to capture changes in prices induced by the marketization of the economy, and a failure to adequately account for regional price differences. They also suggest that urban poverty requires a careful assessment that has heretofore been lacking, and that the exclusive focus on rural poverty might provide a very incomplete picture of poverty in China.

Khan and Riskin (2001) construct poverty lines for rural and urban areas based on the costs of attaining adequate nourishment (interpreted as a given caloric requirement, which is lower in urban areas) and an allowance for non-food consumption expenditure (set in accordance with the non-food expenditures of households at the food poverty line). The poverty line used by these authors is related to a nutritional anchor and constructed with greater transparency than is the official poverty line. The analysis is based on data from the 1988 and 1995 Chinese Household Income Project surveys. The authors identify a rural headcount of 35.1 percent in 1988 and 28.6 percent in 1995, and an urban headcount of 8.2 percent in 1988 and 8.0 percent in 1995. The authors also adjust the official consumer price index so as better to reflect changes over time in the cost of achieving a nutritional minimum. Poverty estimates based on the 'unadjusted' CPI suggest that rural poverty decreased by 19 percent, and urban poverty fell by 2.4 percent between 1988 and 1995. In contrast, the use of the 'adjusted' CPI leads to estimates that poverty fell in the period by only 13 percent in rural areas, and increased in urban areas by almost one fifth.

An assessment of the evolution of urban poverty in China has also been addressed in other related studies. For example, Fang, Zhang and Fan (2002) produce urban poverty estimates using the $\$ 1$ and $\$ 1.5 /$ day poverty lines, as well as the Chinese official poverty line for the period, from 1992 to $1998 .{ }^{5}$ They conclude that the incidence of urban poverty first declined until 1996, only to increase subsequently, and that this result is robust across poverty lines. For 1998, they propose an urban '\$1.50 per day' poverty headcount of eight percent and contrast this to the one percent headcount ratio estimated by Chen and Wang (2001). The discrepancy between the estimates is possibly explained by the fact that Chen and Wang (2001) use grouped income data in constructing their poverty estimates. These are reported for poverty lines ranging from $\$ 0.50 /$ day to $\$ 2.50 /$ day for rural China, urban China and for China as a whole.

Using household-level survey data, Xue and Zhong (2003) estimate a poverty headcount ratio for urban China of 11.6 percent in 1999 (using a poverty threshold of 2,152 Yuan, which they apply nationally without spatial price adjustments). ${ }^{6}$ They offer estimates for six provinces 
(Beijing, Gansu, Henan, Jiangsu, Liaoning and Sichuan) which indicate that urban poverty has been on the rise since 1988. Specifically, their estimates suggest that in these provinces the urban poverty headcount ratio has increased by 36 percent between 1988 and 1995, and by almost 35 percent between 1995 and 1999. Their estimate of the average poverty headcount ratio for the six provinces is 6.7 percent.

Gibson, Huang and Rozelle (2003) investigate (using data from China's 1997 Household Income and Expenditure Survey for urban areas in Hebei and Sichuan provinces) whether poverty (and inequality) estimates vary in accordance with the method of recording consumption (e.g., diaries vs. recall and extrapolation) and the method of extrapolation used to obtain estimates of annual consumption from survey responses. They conclude that if China switched to estimating consumption based on annual figures extrapolated from several monthly responses instead of the current, more costly diary method, the result would be a decrease in estimated levels of consumption and a corresponding increase in the estimated level of poverty.

In a recent study, Chen and Ravallion (2005) use tabulated income data for a number of population fractiles to document China's progress against poverty between 1980 and 2001. The income variable contains the imputed value of own-production, and excludes imputed rents for owner-occupied housing. The authors estimate for each province rural and urban income poverty using the following poverty lines: the 'official' (rural) national poverty line and two nutritionally anchored poverty lines (respectively for urban and rural areas) which incorporate an allowance for non-food consumption (set in accordance with non-food expenditures of households possessing food expenditures corresponding to the food poverty line in the rural and urban sectors respectively). National poverty is estimated using national rural and urban poverty lines defined as the averages of the regional rural and urban poverty lines. The study documents a substantial reduction in national poverty in China, with the poverty headcount ratio (corresponding to the poverty line that represents the average of the rural and urban nutritional poverty lines) having fallen from 53 percent in 1980 to 22 percent in 1990 and eight percent in 2001. Furthermore, most of the poverty reduction is shown to have been driven by rising incomes in rural areas in the first half of the 1980s.

A series of studies present poverty headcounts for China in the context of broader estimates for the world. For example, Berry and Serieux (2004) estimate poverty headcount ratios for China and the world for 1980, 1990 and 2000. The paper concludes that the number of people living under $\$ 500$ per year at 1985 international dollars decreased in China by more than 75 percent. At the same time, the number of people living under $\$ 1500$ per year at 1985 international dollars was halved. Furthermore, world poverty incidence fell from 25.7 in 1980 to 14.6 in 1990 and to 12.1 in 2000.

Chen and Ravallion (2001a) also found a net decrease in world consumption poverty rates between 1987 and 1998 (at the \$1.08/day and the \$2.15/day 1993 PPP adjusted poverty lines) driven mainly by high growth in China. In their more comprehensive study, Chen and Ravallion (2004) conclude that the number of $\$ 1$ day poor people in the world was 1.1 billion in 2001, having decreased from 1.5 billion in 1980. Critically, the number of poor people declined in China by over 400 million since 1980, but more than half of that fall was achieved during the early 1980s. The authors state that if the current observed trends continue, the $\$ 1 /$ day poverty rate for 1990 would be halved by 2015 (which would represent the achievement of the first Millennium Development Goal on poverty reduction for the East and South Asia region). 
Finally, Sala-i-Martin (2002b) uses data on income shares to estimate poverty headcount ratios for the \$1/day and \$2/day (income) poverty lines for the entire world between 1970 and 1998. Using these poverty lines, which depart from previous methodological norms in referring to income rather than consumption, and employing estimates of income based on national income accounts (as opposed to surveys) to obtain income profiles for each country-year, the author contends that the number of $\$ 1$ per day poor declined by 201.3 million between 1970 and 1998. For China, the income poverty headcount ratio is contended to have been 26.7 percent in 1970, and to have steadily declined to 19.8 percent by 1980, 9.7 percent by 1990, and 2.6 percent by 2000 . This represents a fall in the $\$ 1 /$ day poverty headcount by 185.9 million people between 1970 and 1998. An updated set of (income) poverty headcount ratios corresponding to a $\$ 1.5 /$ day poverty line is reported in Sala-i-Martin (2006). The author finds that the poverty headcount ratio in China had been 32 percent in 1970, and declined to 3.1 in 2000.

\section{DATA}

To obtain consumption poverty estimates for China, we use income shares available for the years 1990, 1992 to 1998, and 2001, which we report below: ${ }^{7}$

TABLE 1

Income Shares, China, 1990, 1992-1998 and 2001

\begin{tabular}{|c|c|c|c|c|c|c|c|c|c|}
\hline Year $\rightarrow$ & 1990 & 1992 & 1993 & 1994 & 1995 & 1996 & 1997 & 1998 & 2001 \\
\hline \multicolumn{10}{|l|}{ Deciles $\downarrow$} \\
\hline Bottom & 3.08 & 2.57 & 2.31 & 2.03 & 2.22 & 2.38 & 2.32 & 2.39 & 1.80 \\
\hline Second & 4.25 & 3.60 & 3.31 & 3.32 & 3.28 & 3.51 & 3.52 & 3.47 & 2.86 \\
\hline Third & 5.36 & 4.64 & 4.33 & 4.34 & 4.34 & 4.62 & 4.65 & 4.55 & 3.92 \\
\hline Fourth & 6.49 & 5.73 & 5.40 & 5.40 & 5.48 & 5.75 & 5.80 & 5.65 & 5.08 \\
\hline Fifth & 7.65 & 6.95 & 6.60 & 6.57 & 6.70 & 6.95 & 7.00 & 6.86 & 6.36 \\
\hline Sixth & 8.97 & 8.34 & 7.99 & 7.91 & 8.15 & 8.32 & 8.36 & 8.24 & 7.86 \\
\hline Seventh & 10.55 & 10.1 & 9.74 & 9.55 & 9.93 & 10.01 & 10.01 & 9.93 & 9.74 \\
\hline Eighth & 12.66 & 12.51 & 12.18 & 11.79 & 12.41 & 12.31 & 12.27 & 12.27 & 12.39 \\
\hline Ninth & 16.01 & 16.55 & 16.36 & 15.47 & 16.61 & 16.19 & 16.05 & 16.23 & 16.93 \\
\hline Top & 24.98 & 29.01 & 31.78 & 33.62 & 30.88 & 29.96 & 30.02 & 30.41 & 33.06 \\
\hline
\end{tabular}

The next section presents alternative values for the parameters of interest; these will enable us to transform the income shares above into an income profile (i.e., an average income level attributed to each income group in each year), and finally into a consumption profile (i.e., an average consumption level attributed to each income group in each year).

\section{PLAUSIBLE ALTERNATIVE ASSUMPTIONS}

In this section we construct plausible ranges of variation for each of the four previously identified parameters underlying the poverty analysis: poverty lines ( $P L s)$, estimates of the per capita private income level $(\hat{Y})$, the share of consumption in total income $(\theta)$ and inflation rates $(\pi)$.

\section{POVERTY LINES ( $P L S)$}

First, for a given base year, we identify a set of alternative poverty lines to be used in our analysis of Chinese consumption poverty. We wish these alternative poverty lines to span a 
plausible range. In order to maintain notional comparability with poverty estimates for other countries, it is also desirable for these poverty lines to correspond to poverty lines in use elsewhere. In particular, we focus on the '\$1 per day' money-metric international poverty line. ${ }^{8}$

Since China has never participated in an official benchmark survey of the international comparison program, judgments concerning the 'appropriate' PPP for China have varied widely. These widely discrepant judgments concerning PPPs in turn can have large implications in regard to estimated Chinese poverty levels corresponding to the '\$1 per day' international poverty line (as discussed, for example, in Reddy and Pogge, 2006). As a starting point, we identify alternative specifications of the PPP conversion factor for consumption for China in 1993 that have been presented in the literature. Our approach avoids an endorsement of any existing approach to the construction of PPPs, all of which we consider to be very rough. The reader who is unimpressed either by the international poverty line or by the use of existing PPPs to convert this poverty line into local currency units might consider that the poverty lines that we employ simply reflect a plausible range of variation for poverty lines in China. The sense in which these poverty lines reflect a plausible range of variation is specific: they span the range of poverty lines in the existing literature on Chinese poverty. This does not in itself imply that the poverty lines reflect the cost of avoiding poverty (by establishing command over the commodities needed to achieve basic human requirements) since the poverty lines in the existing literature might well not adequately reflect these costs. There is ultimately no alternative to carefully establishing appropriate criteria for identifying the poor in China. The exercise undertaken in this paper cannot substitute for that effort - which is best undertaken within China on the basis of adequate normative judgments, empirical evidence and relevant contextual considerations.

The upper and lower poverty lines that we adopt are 404.7 and 839.11993 Yuan/year. These two poverty lines are close to the opposite ends of the range of national poverty lines for China proposed in the literature and also happen to correspond to the $\$ 1 /$ day international poverty line under alternative plausible assumptions (see Appendix 3 for details concerning their construction). To show that our chosen poverty lines reflect bounds for plausible national poverty lines considered in the established literature, we report, in Table 2, a set of regional and national poverty lines drawn from it.

TABLE 2

Alternative Poverty Lines for China (Yuan/year, 1993 prices) ${ }^{9}$

\begin{tabular}{|l|l|c|}
\hline \multicolumn{1}{|c|}{ Study } & \multicolumn{1}{|c|}{ Type of poverty line } & Poverty line \\
\hline NBS (2004) & Rural - official & 399.8 \\
\hline Our lower poverty line & National - low & 404.7 \\
\hline NBS (2004) & Rural (low income line) - official & 535.5 \\
\hline Chen and Ravallion (2005) & Rural & 542 \\
\hline Khan and Riskin (2001) & Rural - low & 558.5 \\
\hline Chen and Ravallion (2001a, 2004) & National - \$1.08/day & 559.7 \\
\hline Chen and Ravallion (2005) & National & 645.8 \\
\hline Chen and Ravallion (2005) & Urban & 743.2 \\
\hline Khan and Riskin (2001) & Rural - high & 798.3 \\
\hline Our higher poverty line & National - high & 839.1 \\
\hline Khan and Riskin (2001) & Urban - low & 1098.7 \\
\hline Chen and Ravallion (2001a, 2004) & National - \$2.15/day & $1,113.6$ \\
\hline Xue and Zhong (2003) & Urban & $1,359.9$ \\
\hline Khan and Riskin (2001) & Urban - high & $1,569.4$ \\
\hline
\end{tabular}


We note that our lower poverty line (404.7 Yuan/year) is lower than the lowest national poverty line proposed by Chen and Ravallion (2001a, 2004). In contrast, our highest poverty line (839.1 Yuan/year) is lower than the highest national poverty line of Chen and Ravallion $(2001 a, 2004)$. However, this does not worry us because both the local currency value of this poverty line and the associated headcount ratios are widely viewed as implausibly high for China in the 1990s.

It is appropriate for us to employ a single national poverty line for China since, by assumption, inter-sectoral (in particular rural-urban) and inter-provincial price adjustments have already been undertaken in the process of constructing the income shares with which we begin (reported in Table 1). ${ }^{10}$

\section{PER CAPITA INCOME ESTIMATES $(\hat{Y})$}

Since yearly distributional consumption data are not publicly available for China, the task of computing consumption from income estimates is unavoidable. In this section, we discuss estimates of the per capita true private income $\hat{Y}$ on the basis of which we will obtain an income profile from income shares.

There are discrepant views in the literature on what constitutes an appropriate method for estimating true per capita real income; in particular, some authors take the view that per capita GDP estimates offer the superior measure of private real income and consumption (see, for example, Bhalla 2002, Sala-i-Martin 2002a, 2002b, 2006); in contrast, others advocate the use of survey-based income (and consumption) estimates (see Deaton, 2005). Deaton presents an extensive analysis of differences between survey and national accounts (NA) estimates of consumption and income per capita. These discrepancies are observed for both levels and rates of growth. He shows that, on average, survey-based mean income is 60 percent of GDP (based on data from 272 household surveys), and the same ratio is 51 percent in the East Asia and Pacific region (32 surveys). Furthermore, in non-OECD countries, consumption estimates from surveys in the 1990s appear to have grown slower than NA consumption estimates, while for income estimates the situation is reversed. Furthermore, Deaton argues that China's ratio of survey-to-NA consumption was declining in the 1990s, from 95 percent in 1990 to 80 percent in 2000. Household consumption series from the two sources also differ in terms of growth rates by 1.7 percent a year during the 1990s. Naturally, discrepancies of this level between surveys and NA data can generate large differences in the estimated mean income for different quantile groups, and consequently affect estimated poverty levels.

Similarly, differences arise from the use of per capita aggregate income (GDP) as the measure of household income in China instead of a survey-based estimate of household income (namely, using survey-based annual data on per capita household disposable income from the 2003 China Statistical Yearbook). ${ }^{11}$ We find that the average annual growth rate of income from household surveys between 1990 and 2001 was 7.54 percent. ${ }^{12}$ In contrast, the average annual growth rate of the per capita GDP was 8.74 percent. ${ }^{13}$ This discrepancy in the growth rates of mean per capita income from the two sources is accompanied by a substantial difference in levels (the ratio between the two estimates varies in China between 1.81 (in 1990) and 2.11 (in 1997 and 1998).

We accommodate both views concerning the appropriate method of estimating private per capita incomes. We consider both national accounts-based and survey-based estimates of per capita private incomes (denoted in the remainder of the paper as $\hat{Y}_{N A}$ and $\hat{Y}_{S}$, respectively) to construct income profiles. ${ }^{14}$ 


\section{SHARES OF CONSUMPTION IN TOTAL INCOME $(\theta)$}

Reliable consumption surveys for various years are not publicly available for China. However, existing international poverty lines are specified in terms of levels of consumption (in particular, $\$ 1$ or $\$ 2$ per day). As a result, simplifying assumptions that enable the estimation of consumption poverty without relying directly on consumption information from household surveys have been applied in the literature on Chinese, regional and world poverty (e.g., Chen and Ravallion 2001a, 2004, and Chen and Wang 2001).

Specifically, it has been generally assumed that the consumption to income ratio is constant across income deciles and equal to the share of total household consumption in GDP, as identified in the national income accounts. For our third parameter of interest $\theta$, we denote this estimate by $\theta_{N A}$. We also adopt a more realistic set of consumption to income ratios calculated from household surveys, which we denote $\theta_{S}$. In particular, we use the 1995 Chinese Household Income Project rural and urban surveys to obtain consumption to income $(\mathrm{C} / \mathrm{I})$ ratios for each decile of the national income distribution. ${ }^{15}$ In this way, $\theta_{S}$ improves on $\theta_{N A}$ in two ways: first, the $\mathrm{C} / \mathrm{I}$ ratios in $\theta_{S}$ are based on a household survey rather than the National Accounts.

It is generally agreed that household survey based estimates are more appropriate for the present purpose since we are interested in estimating the consumption of households and national income accounts contain much information that is irrelevant for this purpose. Second, the $\mathrm{C} / \mathrm{I}$ ratios in $\theta_{S}$ are specific to each decile of the income distribution. As a result, we can select those that are most appropriate for estimating the actual consumption of the income groups with which we are concerned. Due to data limitations (the fact that there was only a single year in the 1990s surveyed by the China Household Income Project), we make the assumption that these estimates of the average propensity to consume of each income decile in China held in every year between 1990 and 2001.

\section{INFLATION RATES $(\pi)$}

This section identifies alternative values for the last parameter in our vector: inflation rates $(\pi)$. One immediate candidate is the official general consumer price index $\left(\pi_{\text {off }}\right)$. The official CPI, however, might not accurately reflect the cost of purchasing the commodities needed to achieve elementary human requirements and thereby to avoid poverty. ${ }^{16}$ In order to better account for the cost of consuming such commodities, we create a set of 'adjusted' consumer price indices.

Specifically, we use data from the China Household Income Project survey for 1995 to estimate shares of food (and implicitly of non-food) in total expenditure for the lower quantiles of the income distribution. We use this information to construct an 'adjusted' price index with weights assigned to food and non-food items that correspond to the empirical expenditure shares on these items for the bottom quantiles of the income distribution. Although this is not a wholly satisfactory procedure, it does permit us to improve upon the overall consumer price index, and thus more closely reflect the average pattern of consumption. Decile-specific food shares from the 1995 surveys are reported in Appendix 5C. Noting that the share of food 
expenditure in total expenditure is about sixty percent for the first six deciles of the population, we employ this weight on food in the construction of our adjusted price index.

Two approaches are used to construct adjusted price indices: the first entails using the publicly available general and food CPI, as well as the food and non-food expenditure shares to obtain an 'implied' non-food CPI (treating the general CPI as a weighted average of this implicit non-food CPI and the food CPI, with weights based on expenditure shares). We obtain an 'adjusted' general CPI using this implied non-food CPI, the official food CPI, and food/nonfood shares in total consumption from the surveys.

The second approach uses the food CPI and a proxy for the non-food CPI, as well as a food share of sixty percent (corresponding to the food share for the lower deciles of the income distribution) to obtain 'adjusted' general CPIs. Several CPIs might play the role of proxies for the non-food CPI, namely: (a) the ex-factory price index of industrial products, (b) the means of production price index, and (c) a weighted average of the price indices for clothing, articles for daily use, and durable consumer goods, where the weights are the average weights in the total consumption of these items from the 1995 survey (namely, sixty percent for clothing, thirty percent for daily use items and ten percent for durable consumer goods). From among these three alternatives, our preferred adjusted CPI is the last since it does not rely on a proxy index for non-food items that might incorrectly attribute to consumer prices changes in producers' input or output prices. ${ }^{17}$

In Appendix 6, we report the alternative adjusted indices. We note that there are no substantial differences in the evolution of prices between the official CPI and the 'adjusted' CPIs. Our preferred 'adjusted' CPI most closely resembles the official CPI. At any given point in time, however, the gap between the two price indices varies. As seen below, the use of an adjusted CPI is unlikely to reverse the conclusion of a downward trend in the estimated poverty headcount ratio and has little effect on the extent of poverty. ${ }^{18}$

The two alternative choices for the inflation rate parameter $\pi$ that we employ in subsequent analysis are the official general CPI $\pi_{o f f}$ and the preferred 'adjusted' CPI $\pi_{a d j}$.

\section{CONSUMPTION PROFILES AND POVERTY ESTIMATES}

\section{CONSUMPTION PROFILES}

As noted before, we estimate the average level of income of each decile of the income distribution using both per capita GDP $\left(\hat{Y}_{N A}\right)$ and survey-based average income $\left(\hat{Y}_{S}\right)$. Specifically, we multiply each income share by 10 times our estimate of per capita private income expressed in current LCUs (local currency units) to arrive at this average. The resulting income profiles are presented in Tables 3.1 and 3.2. 
TABLE 3.1

Income Profile (at current prices), $\hat{Y}_{N A}$

\begin{tabular}{|l|r|r|r|r|r|r|r|r|r|}
\hline \multicolumn{1}{|c|}{ Year $\rightarrow$} & \multicolumn{1}{|c|}{$\mathbf{1 9 9 0}$} & \multicolumn{1}{|c|}{$\mathbf{1 9 9 2}$} & \multicolumn{1}{|c|}{$\mathbf{1 9 9 3}$} & $\mathbf{1 9 9 4}$ & $\mathbf{1 9 9 5}$ & $\mathbf{1 9 9 6}$ & $\mathbf{1 9 9 7}$ & $\mathbf{1 9 9 8}$ & $\mathbf{2 0 0 1}$ \\
\hline Deciles $\downarrow$ & & & & & & & & & \\
\hline Bottom & 503.3 & 587.8 & 678.9 & 796.4 & 1077.6 & 1327.1 & 1404.5 & 1507.4 & 1377.2 \\
\hline Second & 694.5 & 823.3 & 972.8 & 1302.4 & 1592.1 & 1957.2 & 2131.0 & 2188.5 & 2188.2 \\
\hline Third & 875.8 & 1061.2 & 1272.6 & 1702.6 & 2106.6 & 2576.1 & 2815.1 & 2869.7 & 2999.2 \\
\hline Fourth & 1060.5 & 1310.5 & 1587.1 & 2118.4 & 2660.0 & 3206.2 & 3511.3 & 3563.5 & 3886.7 \\
\hline Fifth & 1250.0 & 1589.5 & 1939.7 & 2577.4 & 3252.2 & 3875.3 & 4237.8 & 4326.6 & 4866.0 \\
\hline Sixth & 1465.7 & 1907.4 & 2348.3 & 3103.1 & 3956.0 & 4639.2 & 5061.1 & 5197.0 & 6013.7 \\
\hline Seventh & 1723.9 & 2309.9 & 2862.6 & 3746.5 & 4820.0 & 5581.6 & 6060.1 & 6262.9 & 7452.1 \\
\hline Eighth & 2068.6 & 2861.0 & 3579.7 & 4625.2 & 6023.8 & 6864.1 & 7428.3 & 7738.7 & 9479.6 \\
\hline Ninth & 2616.0 & 3785.0 & 4808.2 & 6068.9 & 8062.5 & 9027.5 & 9716.7 & 10236.3 & 12953.1 \\
\hline Top & 4081.7 & 6634.6 & 9340.1 & 13189.1 & 14989.2 & 16705.7 & 18174.1 & 19179.6 & 25294.2 \\
\hline
\end{tabular}

TABLE 3.2

Income Profile (at current prices), $\hat{Y}_{S}$

\begin{tabular}{|c|c|c|c|c|c|c|c|c|c|}
\hline Year $\rightarrow$ & 1990 & 1992 & 1993 & 1994 & 1995 & 1996 & 1997 & 1998 & 2001 \\
\hline \multicolumn{10}{|l|}{ Deciles $\downarrow$} \\
\hline Bottom & 278.4 & 289.2 & 319.9 & 379.5 & 524.7 & 669.7 & 712.2 & 776.8 & 730.5 \\
\hline Second & 384.2 & 405.1 & 458.5 & 620.7 & 775.2 & 987.7 & 1080.6 & 1127.8 & 1160.7 \\
\hline Third & 484.5 & 522.1 & 599.7 & 811.4 & 1025.7 & 1300.0 & 1427.5 & 1478.9 & 1590.9 \\
\hline Fourth & 586.6 & 644.8 & 747.9 & 1009.6 & 1295.1 & 1618.0 & 1780.5 & 1836.4 & 2061.7 \\
\hline Fifth & 691.5 & 782.0 & 914.1 & 1228.4 & 1583.4 & 1955.7 & 2148.9 & 2229.7 & 2581.2 \\
\hline Sixth & 810.8 & 938.4 & 1106.7 & 1478.9 & 1926.1 & 2341.2 & 2566.4 & 2678.2 & 3190.0 \\
\hline Seventh & 953.6 & 1136.5 & 1349.0 & 1785.5 & 2346.8 & 2816.7 & 3072.9 & 3227.5 & 3953.0 \\
\hline Eighth & 1144.3 & 1407.7 & 1687.0 & 2204.3 & 2932.9 & 3463.9 & 3766.6 & 3988.1 & 5028.5 \\
\hline Ninth & 1447.1 & 1862.2 & 2266.0 & 2892.4 & 3925.5 & 4555.7 & 4927.0 & 5275.2 & 6871.1 \\
\hline Top & 2257.9 & 3264.3 & 4401.7 & 6285.8 & 7298.0 & 8430.5 & 9215.5 & 9884.0 & 13417.5 \\
\hline
\end{tabular}

Next, we present several consumption profiles based on various plausible assumptions. First, we present consumption profiles based on the 'least refined' estimate of the share of consumption in income from the national accounts (assumed to be constant across the income distribution); in other words, we apply the ratio $\theta_{N A}$ to the income profiles from Table 3.1 and 3.2 to obtain a consumption profile which we then express at 1993 constant prices with the use of the official general CPI (Tables 4.1, 4.2): 
TABLE 4.1

Consumption Profile (at current prices) $\left(\hat{Y}_{N A}, \theta_{N A}, \pi_{\text {off }}\right.$ )

\begin{tabular}{|c|c|c|c|c|c|c|c|c|c|}
\hline Year $\rightarrow$ & 1990 & 1992 & 1993 & 1994 & 1995 & 1996 & 1997 & 1998 & 2001 \\
\hline \multicolumn{10}{|l|}{ Deciles $\downarrow$} \\
\hline Bottom & 308.3 & 317.5 & 305.5 & 286.7 & 341.9 & 397.3 & 410.0 & 445.6 & 407.1 \\
\hline Second & 425.4 & 444.8 & 437.8 & 468.9 & 505.1 & 585.9 & 622.1 & 646.9 & 646.8 \\
\hline Third & 536.4 & 573.3 & 572.7 & 612.9 & 668.3 & 771.2 & 821.8 & 848.3 & 886.6 \\
\hline Fourth & 649.5 & 707.9 & 714.2 & 762.6 & 843.9 & 959.8 & 1025.0 & 1053.3 & 1148.9 \\
\hline Fifth & 765.6 & 858.7 & 872.9 & 927.9 & 1031.7 & 1160.1 & 1237.1 & 1278.9 & 1438.4 \\
\hline Sixth & 897.7 & 1030.4 & 1056.7 & 1117.1 & 1255.0 & 1388.8 & 1477.5 & 1536.2 & 1777.6 \\
\hline Seventh & 1055.9 & 1247.9 & 1288.2 & 1348.7 & 1529.1 & 1670.9 & 1769.1 & 1851.3 & 2202.8 \\
\hline Eighth & 1267.0 & 1545.6 & 1610.9 & 1665.1 & 1911.0 & 2054.8 & 2168.5 & 2287.5 & 2802.1 \\
\hline Ninth & 1602.3 & 2044.8 & 2163.7 & 2184.8 & 2557.8 & 2702.5 & 2836.5 & 3025.8 & 3828.9 \\
\hline Top & 2500.1 & 3584.2 & 4203.1 & 4748.1 & 4755.2 & 5001.1 & 5305.5 & 5669.4 & 7476.9 \\
\hline
\end{tabular}

TABLE 4.2

Consumption Profile (at current prices) $\left(\hat{Y}_{S}, \theta_{N A}, \pi_{\text {off }}\right.$ )

\begin{tabular}{|l|r|r|r|r|r|r|r|r|r|}
\hline \multicolumn{1}{|c|}{ Year $\rightarrow$} & \multicolumn{1}{c|}{1990} & \multicolumn{1}{c|}{1992} & \multicolumn{1}{c|}{1993} & \multicolumn{1}{c|}{1994} & \multicolumn{1}{c|}{1995} & \multicolumn{1}{c|}{1996} & \multicolumn{1}{c|}{1997} & \multicolumn{1}{c|}{1998} & $\mathbf{2 0 0 1}$ \\
\hline Deciles $\downarrow$ & & & & & & & & & \\
\hline Bottom & 170.5 & 156.2 & 144.0 & 136.6 & 166.4 & 200.5 & 207.9 & 229.6 & 215.9 \\
\hline Second & 235.3 & 218.8 & 206.3 & 223.5 & 245.9 & 295.7 & 315.4 & 333.4 & 343.1 \\
\hline Third & 296.7 & 282.1 & 269.9 & 292.1 & 325.4 & 389.2 & 416.7 & 437.1 & 470.3 \\
\hline Fourth & 359.3 & 348.3 & 336.6 & 363.5 & 410.9 & 484.4 & 519.8 & 542.8 & 609.4 \\
\hline Fifth & 423.5 & 422.5 & 411.4 & 442.2 & 502.3 & 585.5 & 627.3 & 659.1 & 763.0 \\
\hline Sixth & 496.6 & 507.0 & 498.0 & 532.4 & 611.0 & 700.9 & 749.2 & 791.7 & 943.0 \\
\hline Seventh & 584.1 & 614.0 & 607.1 & 642.8 & 744.5 & 843.2 & 897.0 & 954.0 & 1168.5 \\
\hline Eighth & 700.9 & 760.5 & 759.2 & 793.6 & 930.4 & 1037.0 & 1099.6 & 1178.9 & 1486.4 \\
\hline Ninth & 886.4 & 1006.0 & 1019.7 & 1041.3 & 1245.3 & 1363.8 & 1438.3 & 1559.3 & 2031.1 \\
\hline Top & 1383.0 & 1763.5 & 1980.8 & 2262.9 & 2315.2 & 2523.8 & 2690.3 & 2921.7 & 3966.2 \\
\hline
\end{tabular}

We also present the 'most refined' estimates of the consumption profile, namely, those based on the income profiles in Tables 3.1 and 3.2, to which we apply decile-specific consumption to income ratios, and for which we use the adjusted 'preferred' CPI to express the consumption levels at 1993 constant prices (Table 5.1, 5.2): 
TABLE 5.1

Consumption Profile (at 1993 prices) $\left(\hat{Y}_{N A}, \theta_{S}, \pi_{a d j}\right)$

\begin{tabular}{|l|r|r|r|r|r|r|r|r|r|}
\hline \multicolumn{1}{|c|}{ Year $\rightarrow$} & \multicolumn{1}{c|}{1990} & \multicolumn{1}{c|}{1992} & \multicolumn{1}{c|}{$\mathbf{1 9 9 3}$} & \multicolumn{1}{c|}{$\mathbf{1 9 9 4}$} & \multicolumn{1}{c|}{1995} & \multicolumn{1}{c|}{1996} & \multicolumn{1}{c|}{1997} & \multicolumn{1}{c|}{1998} & $\mathbf{2 0 0 1}$ \\
\hline Deciles $\downarrow$ & & & & & & & & & \\
\hline Bottom & 627.7 & 652.4 & 678.9 & 644.5 & 704.0 & 790.6 & 834.9 & 916.7 & 901.6 \\
\hline Second & 666.9 & 703.7 & 749.1 & 811.6 & 800.9 & 897.8 & 975.4 & 1024.8 & 1103.0 \\
\hline Third & 808.3 & 871.6 & 941.7 & 1019.6 & 1018.4 & 1135.7 & 1238.3 & 1291.4 & 1453.0 \\
\hline Fourth & 925.8 & 1018.2 & 1110.9 & 1200.0 & 1216.4 & 1337.0 & 1461.0 & 1516.9 & 1781.1 \\
\hline Fifth & 1060.1 & 1199.7 & 1319.0 & 1418.3 & 1444.8 & 1569.9 & 1713.0 & 1789.2 & 2166.2 \\
\hline Sixth & 1389.3 & 1609.0 & 1784.7 & 1908.5 & 1964.2 & 2100.5 & 2286.4 & 2401.9 & 2992.1 \\
\hline Seventh & 1548.0 & 1846.0 & 2061.1 & 2182.9 & 2267.2 & 2394.1 & 2593.6 & 2742.2 & 3512.6 \\
\hline Eighth & 1831.8 & 2254.8 & 2541.6 & 2657.5 & 2794.1 & 2903.3 & 3135.0 & 3341.3 & 4406.2 \\
\hline Ninth & 2186.0 & 2814.9 & 3221.5 & 3290.6 & 3529.0 & 3603.3 & 3869.8 & 4170.7 & 5681.6 \\
\hline Top & 2799.9 & 4050.4 & 5137.1 & 5870.4 & 5385.8 & 5473.7 & 5941.7 & 6415.0 & 9107.6 \\
\hline
\end{tabular}

TABLE 5.2

Consumption Profile (at 1993 prices) $\left(\hat{Y}_{S}, \theta_{S}, \pi_{a d j}\right)$

\begin{tabular}{|c|c|c|c|c|c|c|c|c|c|}
\hline Year $\rightarrow$ & 1990 & 1992 & 1993 & 1994 & 1995 & 1996 & 1997 & 1998 & 2001 \\
\hline \multicolumn{10}{|l|}{ Deciles $\downarrow$} \\
\hline Bottom & 347.2 & 321.0 & 319.9 & 307.1 & 342.8 & 399.0 & 423.3 & 472.4 & 478.3 \\
\hline Second & 368.9 & 346.2 & 353.0 & 386.8 & 389.9 & 453.1 & 494.6 & 528.1 & 585.1 \\
\hline Third & 447.1 & 428.9 & 443.8 & 485.9 & 495.9 & 573.1 & 627.9 & 665.5 & 770.7 \\
\hline Fourth & 512.1 & 501.0 & 523.6 & 571.9 & 592.3 & 674.7 & 740.9 & 781.7 & 944.8 \\
\hline Fifth & 586.4 & 590.3 & 621.6 & 676.0 & 703.4 & 792.2 & 868.6 & 922.0 & 1149.1 \\
\hline Sixth & 768.5 & 791.7 & 841.1 & 909.6 & 956.3 & 1060.0 & 1159.4 & 1237.8 & 1587.2 \\
\hline Seventh & 856.3 & 908.3 & 971.3 & 1040.4 & 1103.9 & 1208.2 & 1315.1 & 1413.2 & 1863.3 \\
\hline Eighth & 1013.3 & 1109.4 & 1197.8 & 1266.5 & 1360.4 & 1465.1 & 1589.7 & 1721.9 & 2337.3 \\
\hline Ninth & 1209.2 & 1384.9 & 1518.2 & 1568.2 & 1718.2 & 1818.4 & 1962.3 & 2149.3 & 3013.8 \\
\hline Top & 1548.8 & 1992.8 & 2420.9 & 2797.8 & 2622.3 & 2762.3 & 3012.9 & 3305.9 & 4831.2 \\
\hline
\end{tabular}

Since the official and 'adjusted' CPIs do not differ much, we may conclude that most of the difference in consumption means presented in Tables 4 and 5 is explained by the difference between the national accounts based (constant) and survey-based (decile-specific) consumption to income ratios. When using survey-based propensities to consume, average consumption levels of the bottom income decile are twice as high as those based on the NA ratio. For the second income decile, the survey-based mean consumption levels are higher by approximately fifty percent. This difference in estimated means will greatly affect the estimated poverty headcount ratios, as we shall see in the next section.

\section{POVERTY ESTIMATES FOR CHINA}

The poverty headcount ratios corresponding to the two $\$ 1$ day poverty lines are summarized in the tables below. For purposes of comparison, we include Chen and Ravallion (2004) and Chen and Wang (2001) estimates in the same tables, the latter being available for a greater number of years. First, in Table 6, we report poverty headcount ratios for China based on the 'least refined' estimates of the consumption profile (presented in Tables 4.1 and 4.2): 
TABLE 6

Poverty Headcount Ratios (Consumption profile given by: $\theta_{N A}, \pi_{\text {off }}$ )

\begin{tabular}{|c|c|c|c|c|c|c|c|c|c|}
\hline $\begin{array}{c}\text { Set of parameters } \\
\left(P L_{L O W}, \hat{Y}_{N A}\right)\end{array}$ & 1990 & 1992 & 1993 & 1994 & 1995 & 1996 & 1997 & 1998 & 2001 \\
\hline Chen and Ravallion $(2004)$ & 33.0 & $\mathrm{n} / \mathrm{a}$ & 28.4 & $\mathrm{n} / \mathrm{a}$ & $\mathrm{n} / \mathrm{a}$ & 17.4 & $\mathrm{n} / \mathrm{a}$ & $\mathrm{n} / \mathrm{a}$ & 16.6 \\
\hline Chen and Wang $(2001)$ & 31.5 & 29.6 & 29.4 & 25.0 & 22.0 & 17.2 & 17.0 & 17.1 & 17.4 \\
\hline$\left(P L_{L O W}, \hat{Y}_{S}\right)$ & 42.2 & 42.8 & 44.2 & 40.2 & 34.4 & 26.7 & 23.8 & 21.9 & 19.9 \\
\hline$\left(P L_{H I G H}, \hat{Y}_{N A}\right)$ & 50.8 & 43.8 & 43.0 & 39.5 & 34.8 & 28.7 & 25.8 & 24.6 & 23.0 \\
\hline$\left(P L_{H I G H}, \hat{Y}_{S}\right)$ & 83.3 & 79.2 & 79.1 & 77.7 & 70.7 & 64.9 & 61.5 & 58.3 & 49.5 \\
\hline
\end{tabular}

These results show that the trend of considerable poverty reduction identified elsewhere in the literature is robust to the choice among alternative poverty lines. The poverty headcount fell (between 1990 and 2001) by at least half if per capita GDP is taken to be an accurate measure of private incomes, and by 40-52 percent if survey estimates of incomes are considered instead. Although this picture of the trend of poverty reduction is robust to the choice of poverty line, this is not true for the extent of poverty. In particular, poverty headcount estimates vary, depending on the year, by a multiplicative factor of between 0.3 and 3.7 of the Chen and Ravallion estimates.

Next, in Table 7, we report poverty headcount ratios for China based on the 'most refined' consumption profiles (reported in Tables 5.1 and 5.2):

TABLE 7

Poverty Headcount Ratios (Consumption profile given by: $\theta_{S}, \pi_{a d j}$ )

\begin{tabular}{|c|c|c|c|c|c|c|c|c|c|}
\hline $\begin{array}{c}\text { Set of parameters } \\
\left(P L_{L O W}, \hat{Y}_{N A}\right)\end{array}$ & $\mathbf{1 9 9 0}$ & $\mathbf{1 9 9 2}$ & $\mathbf{1 9 9 3}$ & $\mathbf{1 9 9 4}$ & $\mathbf{1 9 9 5}$ & $\mathbf{1 9 9 6}$ & $\mathbf{1 9 9 7}$ & $\mathbf{1 9 9 8}$ & $\mathbf{2 0 0 1}$ \\
\hline$\left(P L_{L O W}, \hat{Y}_{S}\right)$ & $\mathrm{n} / \mathrm{a}$ & $\mathrm{n} / \mathrm{a}$ & $\mathrm{n} / \mathrm{a}$ & $\mathrm{n} / \mathrm{a}$ & $\mathrm{n} / \mathrm{a}$ & $\mathrm{n} / \mathrm{a}$ & $\mathrm{n} / \mathrm{a}$ & $\mathrm{n} / \mathrm{a}$ \\
\hline$\left(P L_{H I G H}, \hat{Y}_{N A}\right)$ & $\mathrm{n} / \mathrm{a}$ & 21.1 & 18.4 & 16.2 & 15.6 & 11.0 & 8.4 & 6.2 & 6.1 \\
\hline Chen and Ravallion $(2004)$ & 33.0 & $\mathrm{n} / \mathrm{a}$ & 28.4 & $\mathrm{n} / \mathrm{a}$ & $\mathrm{n} / \mathrm{a}$ & 17.4 & $\mathrm{n} / \mathrm{a}$ & $\mathrm{n} / \mathrm{a}$ & 16.6 \\
\hline Chen and Wang $(2001)$ & 31.5 & 29.6 & 29.4 & 25.0 & 22.0 & 17.2 & 17.0 & 17.1 & 17.4 \\
\hline$\left(P L_{H I G H}, \hat{Y}_{S}\right)$ & $\mathrm{n} / \mathrm{a}$ & 61.9 & 58.3 & 54.1 & 51.3 & 44.9 & 39.7 & 36.1 & 27.8 \\
\hline
\end{tabular}

As expected, the scenario $\left(P L_{L O W}, \hat{Y}_{N A}\right)$ corresponding to the lower of the two poverty lines and the higher per capita income estimates produces negligible headcount ratios. In contrast, the highest poverty line in association with the lower per capita income estimates $\left(P L_{H I G H}, \hat{Y}_{S}\right)$ produces headcount ratios of a magnitude two times higher than those of Chen and Ravallion. However, the estimates still robustly display a downward trend.

It is notable that our poverty estimates depart markedly in magnitude from official statistics and from those of CR. In particular, the set of assumptions that is most refined results 
in estimates starkly different from those of CR (by a multiplicative factor varying between 0.2 and 2.6). Of course, this partially reflects the choice of poverty lines, which cannot be fully rationalized in the absence of an adequate exercise of poverty line construction based on appropriate normative judgments and empirical evidence from China.

Is the pace of poverty reduction (which we understand to refer to the year- after-year percentage decrease in the poverty headcount ratio) different, according to the estimates constructed here, than that recorded in official statistics? According to the official statistics, the pace of poverty reduction was uneven throughout the 1990s, with the highest achievements being between 1995 and 1999 (when it varied between 13 and 20 percent annually). It has been suggested that this might have been a result of post-1994 grain marketing system reforms (which boosted procurement prices received by poor farmers)..$^{19}$ We do not directly assess this causal claim here, but do note that the official data are consistent with it. However, according to the official statistics, there is no evidence of the pace of poverty reduction having fallen over the period considered. The rate of poverty reduction toward the end of the period is generally no lower than that at the beginning of the decade and sometime higher.

We report the rates of poverty reduction and elasticities of the headcount ratio with respect to aggregate income (often referred to misleadingly as the 'growth elasticity of poverty') implied by our estimates (from Tables 6 and 7) in Appendix 7. We observe that, for estimates based on the unadjusted CPI, the pace of poverty reduction accelerated in 1995 and remained higher than at the beginning of the period until around 1997, regardless of the parameters adopted. However, when the 'adjusted' CPI is used, the pace of poverty reduction fell between 1993/94 and 1994/95 and rose thereafter. This is an instance in which the choice of CPI is quite consequential. Furthermore, under all of the combinations of assumptions considered, a trend of uninterrupted poverty reduction is observed until 2001, with two exceptions: the cases corresponding to the lowest poverty line and the use of the official CPI, for which a very small increase in poverty is observed 1990 and 1993, and a slightly larger increase in poverty is observed between 1998 and 2001. In the official statistics, we note a possible reversal of the trend of falling poverty only later, between 2002 and 2003. Finally, there is no clear trend in the 'growth elasticities of poverty'.

\section{CONCLUSIONS}

The record of poverty reduction in China has a substantial impact on assessments of world poverty. In this paper we have analyzed the extent to which estimates of the extent and trend of poverty in China are sensitive to the choice of assumptions concerning poverty lines, the propensity to consume of lower income groups, inflation rates, and the estimate of per capita income needed to construct an income profile from income shares. In particular, we have identified a range of poverty lines for a given base year (1993) that is plausible in the sense that it spans the range of poverty lines proposed in the existing literature. Simultaneously, the poverty lines employed enjoy notional comparability with poverty lines used in current international poverty assessments. We have used both surveys and national accounts to estimate income levels. Furthermore, we have used consumption to income ratios from both the National Income Accounts and the Chinese Household Income Project (1995) survey to translate income levels into consumption levels. Finally, we have expressed the quantities of interest in 1993 constant prices using both the Chinese official consumer price index and 'adjusted' price indices that 
more closely reflect changes over time in the costs of purchasing the basic goods needed to achieve elementary human requirements and thereby avoid poverty.

We found, in this study, that the conclusion that China has had substantial success in reducing consumption poverty over the 1990s is robust to plausible variation in assumptions. China appears to have enjoyed a truly remarkable reduction in consumption poverty over the decade. Moreover, there is no clear evidence that the rate of reduction in the poverty headcount ratio has fallen over time.

The extent of poverty we identify as prevailing in any year is greatly influenced by the assumptions made, however, and often differs markedly from estimates produced in other sources, such as Chen and Ravallion (2004). In particular, some of the sets of assumptions that we consider result in poverty estimates that are as large as 2.6 times Chen and Ravallion's. However, in view of the prevailing uncertainties concerning the appropriate assumptions to apply, and the absence of adequate information on the real costs of achieving basic human requirements in China, there is reason for caution in accepting any one set of poverty estimates as correct.

Three cautionary notes are in order. First, it should be noted here that after the completion of our research, China's National Statistics Bureau upwardly revised historical data for GDP for the years between 1993 and 2004. This revision affects our estimated consumption profiles in the years 1993-1998 and 2001, and consequently, the poverty estimates for these years that depend on national accounts estimates of per capita income. However, we do not believe that this revision materially affects our conclusions. ${ }^{20}$

Our second cautionary note is that when interpreting the patterns found at the aggregate level, one must exercise caution since such figures might conceal important micro-level variations (at the individual, county or even regional level), which we have not considered at all in this analysis, and which are likely to be of great importance for China. Meng et al. (2004) offer evidence based on survey data in urban China that the nutritional intake for lower income groups has been decreasing throughout the 1990s. Rising food prices between 1993-1996 induced by the liberalization of the grain marketing system and the abolition of the food coupon system are cited as the main causes of nutrition worsening. Evidence on rising urban consumption poverty in the 1990s is also provided by Khan and Riskin (2001), Fang, Zhang and Fan (2002), and Xue and Zhong (2003).

Our third cautionary note is that in light of these findings, it is important to know whether China's success in reducing consumption poverty is matched by achievements in other dimensions of development. Some evidence on health outcomes is given by Minoiu and Reddy (2006), who note that province-level rates of improvement in male and female life expectancy were generally higher in the 1990s than in the previous two decades. However, the authors show that it took China a greater number of years to obtain the same improvements that other countries in the same income bracket obtained, starting with similar initial life expectancies.

Despite these cautionary notes, it is clear that the reduction in consumption poverty in China is truly remarkable and provides a perhaps unique instance of dramatic poverty reduction over a short period of time. It is also clear that a central reason why poverty reduction might have taken place worldwide is that it has taken place in China (Reddy and Minoiu, 2006). 


\section{REFERENCES}

Berry, A. and Serieux, J. (2004), "All about the Giants: Probing the Influences on World Growth and Income Inequality at the End of the 20th Century", CESifo Economic Studies, Vol. 50(1), pp. 133-70.

Bhalla, S. (2002), Imagine There is No Country: Poverty, Inequality and Growth in the Era of Globalization, Institute for International Economics, Washington DC.

Chen, S. and Ravallion, M. (2001a), "How did the world's poorest fare in the 1990s", Review of Income and Wealth, Vol. 47(3), pp. 283-300.

Chen, S. and Ravallion, M. (2001b), "Measuring Pro-Poor Growth", World Bank Policy Research Working Papers No. 450.

Chen, S. and Ravallion, M. (2004), "How have the world's poorest fared since the early 1980s?", World Bank Policy Research Working Paper No. 3341.

Chen, S. and Ravallion, M. (2005), "China's (Uneven) Progress against Poverty", forthcoming, Journal of Development Economics.

Chen, S. and Wang, Y., (2001), "China's growth and poverty reduction: recent trends between 1990 and 1999", World Bank Policy Research Working Paper No. 2651.

Cheng, Y. (1996), "China's grain marketing system reform in 1993-94: empirical evidence from a rural household survey", China Economic Review, Vol. 7(2), pp. 135-153.

China State Statistical Bureau (2003), China Statistical Yearbook, Beijing: China Statistical Press.

Datt, G. (1998), "Computational tools for poverty measurement and analysis", International Food Policy Research Institute, Food Consumption and Nutrition Division Discussion Paper No. 50.

Deaton, Angus (2005), "Measuring Poverty in a Growing World (or Measuring Growth in a Poor World)", Review of Economics and Statistics, Vol. 87(1), pp. 1-19.

Fang. C., Zhang, X. and Fan, S. (2002), "Emergence of Urban Poverty and Inequality in China: Evidence from Household Survey", China Economic Review, Vol. 13(4), pp. 430-443.

Gibson, J., Huang, J. and Rozelle, S. (2003), "Improving Estimates of Inequality and Poverty from Urban China's Household Income and Expenditure Survey", Review of Income and Wealth, Volume 49(1), pp. 53-68.

Gulde, A. M. and Schulze-Ghattas, M. (1993), "Purchasing Power Parity Based Weights for the World Economic Outlook", in Staff Studies for the World Economic Outlook, International Monetary Fund, Washington DC.

Havinga, I. and G. Kamanou (2003), "The Use of National Accounts for Estimating the \$1/day per person Global Poverty Measure", paper presented at the Global Poverty Workshop, Carnegie Council on Ethics and International Affairs (March 31-April 1), forthcoming in Anand, S., P. Segal and J. Stiglitz, eds.: Measuring Global Poverty, Oxford University Press.

Khan, A.R. (2004), "Growth, Poverty and Inequality in China: A Comparative Study of the Experience in the Periods Before and After the Asian Crisis", International Labor Organization Issues in Employment and Poverty Discussion Paper no. 15.

Khan, A.R. and Riskin, C. (2001), Inequality and Poverty in China in the Age of Globalization, Oxford University Press. 
Meng, X., Gong, X. and Wang, Y. (2004), "Impact of Income Growth and Nutrition Intake in Urban China: 1986-2000", Institute for the Study of Labor (IZA) Discussion Paper No. 1448.

Minoiu, C. and Reddy, S. (2006), “China's Health Achievements in Comparative Perspective: A Note", mimeo, Columbia University.

National Bureau of Statistics China (2004), "Poverty Statistics in China", paper presented at the International Conference on Official Poverty Statistics (October 4-6), Manila, Philippines.

Available on: <http://www.nscb.gov.ph/poverty/conference/papers/> (accessed July 5, 2006).

Park, A. and Wang, S. (2001), "China's Poverty Statistics", China Economic Review, Vol. 12(4), pp. 384-398.

Rawski, T. (2002), "Measuring China's recent GDP growth: where do we stand?", Chineselanguage version forthcoming in Jingjixue, China Economic Quarterly, Vol. 2(1). Available on: <http://www.pitt.edu/ tgrawski/papers2002/measuring.pdf > (accessed July 5, 2006).

Reddy, S. and Pogge, T. (2006), "How Not to Count the Poor", forthcoming in Anand, S., P. Segal and J. Stiglitz, eds.: Measuring Global Poverty, Oxford University Press. Available on:

$<$ www.socialanalysis.org $>$.

Reddy, S. and Minoiu, C. (2006), "Has World Poverty Really Fallen in the 1990s?", mimeo, Columbia University. Available on: <www.socialanalysis.org $>$.

Riskin, C. (2004), "The Fall in Chinese Poverty: Issues of Measurement, Incidence and Cause", mimeo, Columbia University.

Ruoen, R. and C. Kai. (1995), "China's GDP in U.S. Dollars Based on Purchasing Power Parity", World Bank Policy Research Working Paper No. 1415.

Sala-i-Martin, X. (2002a), "The world distribution of income (estimated from individual country distributions)", National Bureau of Economic Research Working Paper No. 8933.

Sala-i-Martin, X. (2002b), "The 'disturbing' rise of world income inequality", National Bureau of Economic Research Working Paper No. 8904.

Sala-i-Martin, X. (2006), "The World Distribution of Income: Falling Poverty and Convergence, Period", Quarterly Journal of Economics, Vol. 121(2), pp. 351-397.

Singapore Department of Statistics (2001), "Consumer Price Index in China”, material for the International Workshop on Consumer Price Index, 4-8 June 2001. Available on:

$<$ http://www.singstat.gov.sg/conferences/cpi/papers/china.pdf > (accessed July 5, 2006).

Sundaram, K. and Tendulkar, S. (2001), "NAS-NSS Estimates of Private Consumption for Poverty Estimation: A Disaggregated Comparison for 1993-1994", Economic and Political Weekly, No. 119.

Wang, P. and Ren, T. (2004), “Development-Oriented Poverty Alleviation and Monitoring in China", in Gsänger, H. and M. Fernando, eds.: Poverty Monitoring in Asia, Edited Volume No. 32004, Centre for Poverty Analysis, Colombo.

World Development Indicators online (2003), Washington DC: World Bank Group.

Xue, J. and Zhong, W. (2003), "Unemployment, poverty and income disparity in urban China", Asian Economic Journal, Vol. 17(4), pp. 383-405.

Yao, S. (2000), "Economic development and poverty reduction in China over 20 years of reform", Economic Development and Cultural Change, Vol. 48(3), pp. 447-489. 


\section{APPENDIX 1 - CHINESE, EAST ASIAN AND DEVELOPING WORLD POVERTY ESTIMATES}

TABLE A1.1

\section{Chen and Ravallion (2004); Poverty line: \$1.08/day at PPP}

\begin{tabular}{|c|c|c|c|c|c|c|c|c|}
\hline \multirow[b]{2}{*}{ Year $\rightarrow$} & \multicolumn{8}{|c|}{ Poverty headcount index, \$1.08/day 1993 consumption PPP adjusted poverty line } \\
\hline & 1981 & 1984 & 1987 & 1990 & 1993 & 1996 & 1999 & 2001 \\
\hline East Asia & 57.7 & 38.9 & 28.0 & 29.6 & 24.9 & 16.6 & 15.7 & 14.9 \\
\hline China $^{21}$ & 63.8 & 41.0 & 28.5 & 33.0 & 28.4 & 17.4 & 17.8 & 16.6 \\
\hline $\begin{array}{l}\text { East Asia w/out } \\
\text { China }\end{array}$ & 42.0 & 33.5 & 27.0 & 21.1 & 16.7 & 14.7 & 11.0 & 10.8 \\
\hline World & 40.4 & 32.8 & 28.4 & 27.9 & 26.3 & 22.8 & 21.8 & 21.1 \\
\hline World w/out China & 31.7 & 29.8 & 28.4 & 26.1 & 25.6 & 24.6 & 23.1 & 22.5 \\
\hline
\end{tabular}

TABLE A1.2

Official rural poverty estimates (NBS, 2004); Poverty line: approximately \$0.75/day at PPP

\begin{tabular}{|c|c|c|c|c|c|c|c|c|c|}
\hline Year & $\begin{array}{c}\text { Poverty } \\
\text { headcount } \\
\text { ratio }\end{array}$ & $\begin{array}{l}\text { Poverty } \\
\text { head- } \\
\text { count } \\
\text { ratio }\end{array}$ & $\begin{array}{l}\text { Number } \\
\text { of poor } \\
\text { (mil.) }\end{array}$ & $\begin{array}{l}\text { Number } \\
\text { of poor }{ }^{23} \\
\text { (mil.) }\end{array}$ & $\begin{array}{c}\text { Year } \\
\text { onyear } \\
\text { percentage } \\
\text { decrease in } \\
\text { headcount } \\
\text { ratio }\end{array}$ & $\begin{array}{c}\text { Average } \\
\text { percentage } \\
\text { points } \\
\text { decrease in } \\
\text { headcount } \\
\text { ratio }\end{array}$ & $\begin{array}{c}\text { Per } \\
\text { capita } \\
\text { GDP in } \\
\text { constant } \\
\text { LCUs }\end{array}$ & $\begin{array}{c}\text { Average } \\
\text { annual } \\
\text { per } \\
\text { capita } \\
\text { GDP }^{24} \\
\text { growth } \\
\text { rate }\end{array}$ & $\begin{array}{c}\text { "Growth } \\
\text { elasticity } \\
\text { of } \\
\text { poverty" }\end{array}$ \\
\hline 1978 & 30.7 & & 250.0 & & & & 688.14 & & \\
\hline 1984 & 15.1 & & 128.0 & & -0.11 & -2.6 & 1079.34 & 0.08 & -1.43 \\
\hline 1985 & 14.8 & & 125.0 & & -0.02 & -0.3 & 1208.48 & 0.12 & -0.17 \\
\hline 1986 & 15.5 & & 131.0 & & 0.05 & 0.7 & 1295.41 & 0.07 & 0.66 \\
\hline 1987 & 14.3 & & 122.0 & & -0.08 & -1.2 & 1422.68 & 0.10 & -0.79 \\
\hline 1988 & 11.1 & & 96.0 & & -0.22 & -3.2 & 1558.16 & 0.10 & -2.35 \\
\hline 1989 & 11.6 & & 102.0 & & 0.05 & 0.5 & 1597.36 & 0.03 & 1.79 \\
\hline 1990 & 9.4 & & 85.0 & & -0.19 & -2.2 & 1633.91 & 0.02 & -8.29 \\
\hline 1992 & 8.8 & & 80.0 & & -0.03 & -0.3 & 1985.50 & 0.10 & -0.32 \\
\hline 1994 & 7.7 & & 70.0 & & -0.06 & -0.6 & 2480.29 & 0.12 & -0.55 \\
\hline 1995 & 7.1 & & 65.4 & & -0.08 & -0.6 & 2711.10 & 0.09 & -0.84 \\
\hline 1997 & 5.4 & & 49.6 & & -0.13 & -0.9 & 3166.56 & 0.08 & -1.58 \\
\hline 1998 & 4.6 & & 42.1 & & -0.15 & -0.8 & 3380.96 & 0.07 & -2.19 \\
\hline 1999 & 3.7 & & 34.1 & & -0.20 & -0.9 & 3589.79 & 0.06 & -3.17 \\
\hline 2000 & 3.4 & & 32.1 & & -0.08 & -0.3 & 3846.54 & 0.07 & -1.13 \\
\hline 2001 & 3.2 & 9.7 & 29.2 & 90.3 & -0.06 & -0.2 & 4105.10 & 0.07 & -0.88 \\
\hline 2002 & 3.0 & 9.2 & 28.2 & 86.5 & -0.06 & -0.2 & 4403.91 & 0.07 & -0.86 \\
\hline 2003 & 3.1 & 9.1 & 29.0 & 85.2 & 0.03 & 0.1 & 4774.83 & 0.08 & 0.40 \\
\hline
\end{tabular}




\section{APPENDIX 2 - POVCAL}

To estimate the poverty headcount ratio from grouped data, we use the World Bank's POVCAL software. The software fits the Lorenz curve via two parametric interpolation methods: the General (GQ) and the Beta model (Datt, 1998). The results reported in this paper are based on the first method since POVCAL systematically indicates that it provides a better fit to the data. ${ }^{25}$

The two estimation techniques fit the Lorenz curve from grouped income data (e.g., from income means for ten quantiles of the income distribution). Here, we investigate how well the two parametric estimation methods perform in replicating certain features of the distribution of income (such as the poverty headcount ratio for a given poverty line), when grouped income data are available instead of the full underlying survey. To do so, we use the full survey obtained by pooling together the 1995 Chinese Household Income Project urban and rural surveys. ${ }^{26}$ We compute poverty headcount ratios for a range of poverty lines between the median and one-fifth of the median of the underlying survey income in order to reflect the range of variation of poverty lines used later on in the paper.

TABLE A2.1

Estimates of headcount ratios based on grouped income data versus underlying survey data (\%)

\begin{tabular}{|l|c|c|c|}
\hline \multirow{2}{*}{ Poverty line } & \multirow{2}{*}{ Full underlying survey } & \multicolumn{2}{|c|}{ Grouped income data } \\
\cline { 3 - 4 } & & GQ method & Beta method \\
\hline Median & 50.01 & 49.62 & 50.53 \\
\hline 3/4ths of median & 33.63 & 34.26 & 34.46 \\
\hline 1/2 of median & 18.25 & 19.65 & 18.07 \\
\hline 1/3rd of median & 11.20 & 11.42 & 9.55 \\
\hline 1/4th of median & 8.59 & 7.85 & 6.52 \\
\hline 1/5th of median & 6.95 & 5.89 & 5.10 \\
\hline
\end{tabular}

TABLE A2.2

Estimates of headcount ratios based on grouped income data versus underlying survey data (expressed as ratio = grouped data estimate / survey estimate)

\begin{tabular}{|l|c|c|}
\hline Poverty line & GQ method & Beta method \\
\hline Median & 0.992 & 1.010 \\
\hline 3/4ths of median & 1.019 & 1.025 \\
\hline 1/2 of median & 1.077 & 0.990 \\
\hline 1/3rd of median & 1.020 & 0.853 \\
\hline 1/4th of median & 0.913 & 0.759 \\
\hline 1/5th of median & 0.848 & 0.735 \\
\hline
\end{tabular}




\section{APPENDIX 3 - CONSTRUCTION OF ALTERNATIVE POVERTY LINES}

Our strategy consists of the following two steps:

First, we identify 'real' per capita GDP estimates for China in 1990 in 1990 'international dollars' (also known as PPP dollars) from different sources (IMF, World Bank (1993), Ruoen and Kai (1995) and the Penn World Table Version 5.5). To start, we use the GDP estimates for 1991 in 1991 international dollars for China, summarized in Gulde and Schulze-Ghattas (1993, p.117):

TABLE A3.1

Alternative estimates of China's 1991 total GDP* (US\$ billions at 1991 international prices)

\begin{tabular}{|l|c|}
\hline IMF (World Economic Outlook) & $\$ 1,413$ \\
\hline World Bank (1993) & $\$ 1,931$ \\
\hline Penn World Table Version 5.5 & $\$ 3,439$ \\
\hline
\end{tabular}

* Source: Gulde and Schulze-Ghattas (1993, p.117)

China's population in 1991 was 1.15078 billion (World Development Indicators, 2003). This implies the per capita GDP estimates for 1991 (at 1991 international prices) shown in Table A3.2, to which we add Ruoen and Kai's (1995, p. 390) estimate:

TABLE A3.2

Alternative estimates of China's 1991 per capita GDP (1991 international prices)

\begin{tabular}{|l|c|}
\hline IMF (World Economic Outlook) & $\$ 1,227.86$ \\
\hline World Bank (1993) & $\$ 1,677.99$ \\
\hline Rouen and Kai (1995) & $\$ 1,680.00$ \\
\hline Penn World Table Version 5.5 & $\$ 2,988.41$ \\
\hline
\end{tabular}

We obtain an estimate of China's per capita GDP at 1990 international prices using the US GDP deflators for 1990 (88) and 1991 (91) (World Development Indicators, 2003). Applying the ratio between the GDP deflators to convert China's per capita GDP estimates for 1991 from 1991 prices to 1990 prices, we obtain:

TABLE A3.3

Alternative estimates of China's 1991 per capita GDP (1990 international prices)

\begin{tabular}{|l|l|}
\hline IMF (World Economic Outlook) & $\$ 1,187.38$ \\
\hline World Bank (1993) & $\$ 1,622.67$ \\
\hline Rouen and Kai (1995) & $\$ 1,624.62$ \\
\hline Penn World Table Version 5.5 & $\$ 2,889.89$ \\
\hline
\end{tabular}

Next, we use China's per capita real GDP growth rate for the year 1990, of 2.3 per cent (World Development Indicators, 2003) to infer the 1990 per capita GDP at 1990 prices. 
TABLE 3.4

Alternative estimates of China's 1990 per capita GDP (1990 international prices)

\begin{tabular}{|l|r|}
\hline IMF (World Economic Outlook) & $\$ 1,160.82$ \\
\hline World Bank (1993) & $\$ 1,586.38$ \\
\hline Rouen and Kai (1995) & $\$ 1,588.27$ \\
\hline Penn World Table Version 5.5 & $\$ 2,825.25$ \\
\hline
\end{tabular}

Second, we obtain from these alternative per capita GDP estimates for 1990 (in 1990 prices) implicit GDP and consumption PPPs for China. We then derive consumption PPPs for 1993 - the base year used in existing money-metric international poverty estimates. Finally, we identify corresponding ' $\$ 1$ per day' poverty lines for this base year.

Drawing on the range of GDP estimates from Table A3.4 and exercising our judgment, we identify two imperfectly representative estimates of China's 1990 per capita GDP (at 1990 international prices): $\$ 2,695$ and $\$ 1,300$. We then obtain the GDP purchasing power parity conversion factors by dividing China's per capita GDP in 1990 local currency units by these 'real' per capita GDP estimates in US\$. The 1990 per capita GDP in 1990 local currency units was 1,634 Yuan (World Development Indicators, 2003). Therefore, the GDP PPPs (at 1990 international prices) that correspond to the selected per capita GDP estimates are: $0.6063 \mathrm{Y} / \$$ and $1.2569 \mathrm{Y} / \$$.

To obtain consumption PPPs from these GDP PPPs, we use the 1993 World Bank estimate of China's consumption PPP of $1.419 \mathrm{Y} / \$$. There are two approaches to this. In the first method, we move the 1990 GDP PPPs forward in time to 1993 by using the GDP deflators for China and the U.S. respectively to transform their numerator and denominator. We then assume that the ratio of 1993 WB GDP PPP to WB consumption PPP ratio can be applied to the PPPs we have just arrived at and thereby obtain four 1993 consumption PPPs. These will be referred to as Method I consumption PPPs. The second method consists of first computing the ratio between the 1990 WB GDP PPP and the 1990 WB consumption PPP. Applying this ratio as a multiplicative factor to the other 1990 GDP PPP estimates enables us to obtain the corresponding 1990 consumption PPPs. These are moved forward to 1993 using the official Chinese CPI to transform the numerator (from $1990 \mathrm{Y}$ to $1993 \mathrm{Y}$ ) and using the U.S. CPI to transform the denominator (from 1990 \$ to 1993 \$). The resulting figures are referred to as Method II consumption PPPs.

Method I and Method II 1993 consumption PPPs are reported in Table A3.5. We note that within each method, the PPPs vary by a factor of two, but across methods they are of similar magnitude. Alternative estimates of the $\$ 1.08 /$ day WB annual international consumption poverty line at 1993 prices are obtained by multiplying $\$ 1.08$ by each consumption PPP and 365 days. The poverty lines are reported in Table 2 . The alternative poverty lines vary significantly, with the highest poverty line being more than twice as high as the lowest poverty line. The two poverty lines reflect the variation in implicit PPPs associated with variant GDP estimates for China. They are expressed in private Yuan consumption units. 
TABLE A3.5

Consumption PPPs and Poverty Lines (at 1993 prices)

\begin{tabular}{|l|c|c|}
\hline \multirow{2}{*}{ Method I } & Consumption PPPs: & Poverty lines \\
\hline \multirow{2}{*}{ Method II } & $P P P_{L O W}=1.0267 \mathrm{Y} / \$$ & $P L_{L O W}=404.7251 \mathrm{Y} /$ year \\
\cline { 2 - 3 } & $P P P_{H I G H}=2.1285 \mathrm{Y} / \$$ & $P L_{H I G H}=839.0547 \mathrm{Y} /$ year \\
\cline { 2 - 3 } & $P P P_{L O W}=0.9637 \mathrm{Y} / \$$ & $P L_{L O W}=379.8905 \mathrm{Y} /$ year \\
\cline { 2 - 3 } & $P P P_{H I G H}=1.9978 \mathrm{Y} / \$$ & $P L_{H I G H}=787.5328 \mathrm{Y} /$ year \\
\hline
\end{tabular}

Because Method I and Method II PPPs and associated poverty lines are very close, for the remainder of the analysis, we present poverty estimates based only on Method I PPPs and the corresponding poverty lines (namely, 404.7 and 839.11993 Yuan/year). ${ }^{27}$ 


\section{APPENDIX 4 - SURVEY-BASED VS. NATIONAL ACCOUNTS INCOME ESTIMATES}

The source of the National Accounts data is World Development Indicators 2003. We find that the average annual growth rate of per capita GDP (in constant LCUs) between 1990 and 2001 was 8.74 percent. Based on the per capita disposable income estimates for rural and urban households, and rural and urban population shares in China's total population reported in the 2003 China Statistical Yearbooks (Tables $10-3^{28}$ and 4-1), we find that the mean per capita real income level based on surveys grew between 1990 and 2001 by 7.5 percent per year on average. ${ }^{29}$

TABLE A4.1

Comparison of levels and growth rates of national accounts and survey-based national income levels (constant 1990 prices, official China CPI)

\begin{tabular}{|c|c|c|c|}
\hline Year & $\begin{array}{c}\text { NA per capita GDP in } \\
\text { constant LCUs (Yuan) }\end{array}$ & $\begin{array}{c}\text { Survey-based per capita } \\
\text { income (Yuan) }\end{array}$ & $\begin{array}{c}\text { Ratio between NA and } \\
\text { survey-based incomes }\end{array}$ \\
\hline 1990 & 1633.91 & 903.89 & 1.81 \\
\hline 1991 & 1760.05 & 943.76 & 1.86 \\
\hline 1992 & 1985.50 & 1022.76 & 2.03 \\
\hline 1993 & 2227.78 & 1097.60 & 2.08 \\
\hline 1994 & 2480.29 & 1193.89 & 2.10 \\
\hline 1995 & 2711.10 & 1288.75 & 2.08 \\
\hline 1996 & 2940.38 & 1416.87 & 2.11 \\
\hline 1997 & 3166.56 & 1503.61 & 2.11 \\
\hline 1998 & 3380.96 & 1604.83 & 2.06 \\
\hline 1999 & 3589.79 & 1741.45 & 2.08 \\
\hline 2000 & 3846.54 & 1851.35 & 2.04 \\
\hline 2001 & 4105.10 & 2010.21 & Average ratio: 2.02 \\
\hline & Average annual growth rate: & Average annual growth rate: & Median ratio: 2.07 \\
\hline
\end{tabular}




\section{APPENDIX 5}

\section{APPENDIX 5A \\ THE INCOME VARIABLES FROM THE CHINESE HOUSEHOLD INCOME PROJECT SURVEYS 1995}

The Chinese Household Income Project 1995, as well as the SAS codes for constructing measures of disposable rural and urban per capita income, are publicly available through the Inter-university Consortium for Political and Social Research, 2000. A related publication that makes use of income components obtained from this survey is Khan and Riskin (2001). We have been able to replicate most of the variables used in this publication; however, we have found that the per capita income from the rural surveys did not include the value of self-consumption of farm products (mnemonic: RY4), which led to an underestimation of disposable rural income. Correspondence with the authors indicates that the value of self-consumption of farm products is included in 'net farm income' (mnemonic: RY3C). This is also mentioned in the documentation accompanying the surveys ("Estimating Household Income" file). The publication indicates that (p. 31): "RY4 (self-consumption of food) is a category that was separately identified in 1988 and is included in RY3A in 1995". According to the documentation, RY3A is the mnemonic for "net cash income from the sale of farm products", while RY3C = RY3A + RY4.

Two observations are in order:

- $\mathrm{RY} 4$ is the (gross) value of self-consumption. It is a 'gross' value in that the costs associated with producing food for self-consumption are not subtracted from it. Therefore, RY4 can enter total consumption measures, ${ }^{30}$ but it is its 'net' form that should be treated as a component of income;

- The Chinese Household Income Project 1995 does not attempt to separately identify the costs associated with producing agricultural output for sale vs. those for self-consumption. This is standard practice in household level surveys since the separate identification of these costs may be practically impossible for farmers. Therefore, identifying the 'net' value of self-consumption is, in practice, a difficult task.

The cash income from the sales of agricultural output is a ready-made variable in the survey. We attempted to re-construct this variable from scratch by summing up the cash income from the following household farming operations: grains, economic crops, forestry, animal husbandry, fishing and other agricultural activities. The costs of production are those associated with all these activities, and also include the costs associated with producing food for self-consumption. The measure of RY3A obtained from this exercise is identical to that obtained by the authors for 65 percent of the individuals in the rural sample. We can find no explanation for the discrepancy for the remaining 35 percent of the individuals $\left(10,107\right.$ observations). ${ }^{31}$

We proceeded to include RY4 in the measure of total consumption, and in that of total income. This is justified on the basis that, according to the SAS codes, neither is RY4 directly included in total income, nor did we find any conclusive evidence that it is included in any of the components of total income (such as RY3A). Furthermore, once we subtract the total costs of agricultural production (where the production may be either sold or self-consumed), RY4 is also the correct variable to be added to the total income variable. 


\section{APPENDIX 5B SURVEY-BASED CONSUMPTION TO INCOME RATIOS}

To obtain consumption to income ratios for each income decile, we use the Chinese Household Income Project 1995 survey. For rural areas, the measure of total consumption includes the expenditure on staple food, non-staple food, cigarettes and alcoholic beverages, clothing, transport and communications, daily use consumption goods, durable goods, medical care, education, housing, supporting parents or aged relatives, gifts, medical insurance, fines, as well as the expenditure on purchasing fixed capital for production, and taxes and fees. Total consumption also includes the gross value of self-consumption of farm products. We validate the quality of this consumption variable by correlating it to the total cash expenditure on consumption (available in the survey); the correlation is 0.9885 . For urban areas, the total consumption expenditure is available in the survey and is the summation of expenditures on consumption categories that include: food, cigarettes and alcohol, clothing, daily consumer goods, durable consumer goods, non-commodities, labor and other services, educational and reference materials, tuition and fees, children's education, adult education and training, child care, alimony, gifts, transportation, water and electricity, fuel, telephone use, and medical care. The income variables on the basis of which we construct deciles are computed using the publicly available SAS codes that accompany the survey.

To obtain consumption to income ratios for each decile of the income distribution, we put together the rural and the urban surveys in a national survey, which contains 56,437 observations. It is interesting to note that more than 6,400 individuals are dis-saving and are primarily concentrated in the bottom decile:

TABLE A5B

Consumption to income ratios, 1995

\begin{tabular}{|l|c|}
\hline Income deciles $\downarrow$ & Average consumption to income ratio \\
\hline Bottom & $124 \%$ \\
\hline Second & $77 \%$ \\
\hline Third & $74 \%$ \\
\hline Fourth & $70 \%$ \\
\hline Fifth & $68 \%$ \\
\hline Sixth & $76 \%$ \\
\hline Seventh & $72 \%$ \\
\hline Eighth & $71 \%$ \\
\hline Ninth & $67 \%$ \\
\hline Top & $55 \%$ \\
\hline
\end{tabular}

Individuals in the bottom income decile appear to consume, on average, 124 percent of their income. Our procedure requires us to assume that this ratio is representative of the true consumption to income ratio throughout the 1990s. We are concerned, therefore, that the 124 percent figure implies a degree of persistent dis-saving that is implausibly high. This figure also implies that consumption levels for the bottom income decile are greater than for the second income decile, which is also implausible. To address both of these problems, we assume that the consumption to income ratio for the bottom decile is 100 percent. This yields the consumption levels reported in Table 5. 


\section{APPENDIX 5C \\ FOOD SHARES IN TOTAL EXPENDITURE}

To obtain consumption to income ratios for each income decile, we use the Chinese Household Income Project 1995 survey. The total consumption variables are those introduced in Appendix 5b. The rural income variable is discussed in Appendix 5a, while the urban income variable is produced with the SAS codes (from the documentation). To obtain food shares in total expenditure for each decile of the income distribution, we put together the rural and the urban surveys in an overall national survey, which contains 56,437 observations:

TABLE A5C. 1

Food shares in total expenditure, 1995

\begin{tabular}{|l|c|}
\hline Income deciles $\downarrow$ & Food share in total expenditure \\
\hline Bottom & $62 \%$ \\
\hline Second & $63 \%$ \\
\hline Third & $62 \%$ \\
\hline Fourth & $61 \%$ \\
\hline Fifth & $59 \%$ \\
\hline Sixth & $58 \%$ \\
\hline Seventh & $56 \%$ \\
\hline Eighth & $54 \%$ \\
\hline Ninth & $52 \%$ \\
\hline Top & $49 \%$ \\
\hline
\end{tabular}




\section{APPENDIX 6 - 'ADJUSTED' CONSUMER PRICE INDICES}

To construct adjusted consumer price indices, we use two approaches. The first approach entails using the publicly available general CPI and food CPI, as well as the average food shares from the 1995 survey to obtain an 'implied' non-food CPI. We then use the implied non-food CPI, as well as the food CPI and a weight on the food CPI of 60 per cent to obtain the 'adjusted' general CPI. (The weight on the food CPI is motivated by the fact that the food share in total expenditure for the bottom 20 per cent of the population is 62.5 per cent and the food share for the national sample is 57.7 per cent). The second approach uses the food CPI and different proxies for the non-food CPI, as well as a food share of 60 per cent to obtain the 'adjusted' general CPI. The proxies for the non-food CPI that are considered are the ex-factory price index of industrial products, the means of production index, as well as an index constructed from scratch using the 1995 surveys.

2(a). First proxy: ex-factory price index of industrial products (also known as the total industry products price index).

2(b). Second proxy: means of production price index

2(c). Third proxy: a weighted average of the clothing, articles for daily use, and durable consumer goods price indices, where the weights are those in total consumption of these items from the 1995 survey (10 per cent for durable goods, 60 per cent for clothing, and 30 per cent for daily use consumer goods). This is our preferred 'adjusted' CPI (see explanation in text).

The adjusted CPIs resulting from the application of each of these methods are described in the following table:

TABLE A6.1

'Adjusted' CPIs (1993=100):

\begin{tabular}{|c|c|c|c|c|c|}
\hline & Official CPI & \multicolumn{4}{|c|}{ 'Adjusted' CPIs } \\
\hline & & $\mathbf{1}$ & $\mathbf{2 ( a )}$ & $\mathbf{2 ( b )}$ & $\begin{array}{c}\text { 2(c) } \\
\text { preferred - }\end{array}$ \\
\hline 1990 & 79.25 & 78.65 & 74.13 & 72.26 & 80.18 \\
\hline 1991 & 81.94 & 81.21 & 76.85 & 74.48 & 82.95 \\
\hline 1992 & 87.18 & 86.96 & 84.09 & 82.13 & 90.09 \\
\hline 1993 & 100.00 & 100.00 & 100.00 & 100.00 & 100.00 \\
\hline 1994 & 124.10 & 125.37 & 127.67 & 126.73 & 123.57 \\
\hline 1995 & 146.07 & 148.70 & 153.71 & 152.12 & 153.07 \\
\hline 1996 & 158.19 & 160.85 & 163.23 & 161.86 & 167.86 \\
\hline 1997 & 162.62 & 164.52 & 162.96 & 161.60 & 168.23 \\
\hline 1998 & 161.32 & 162.51 & 157.33 & 155.79 & 164.44 \\
\hline 1999 & 159.06 & 159.46 & 151.54 & 150.35 & 157.73 \\
\hline 2000 & 159.70 & 159.29 & 149.99 & 149.75 & 152.95 \\
\hline 2001 & 158.42 & 158.23 & 149.40 & 149.21 & 152.75 \\
\hline Increase in & & & & & $190.51 \%$ \\
\hline $\begin{array}{c}\text { prices } \\
\text { b/w 1990-2001 }\end{array}$ & $199.91 \%$ & $201.18 \%$ & $201.55 \%$ & $206.48 \%$ & \\
\hline
\end{tabular}




\section{APPENDIX 7 - PACE OF POVERTY REDUCTION}

TABLE A7.1

Average annual \% change in headcount ratios (Consumption profile given by: $\theta_{N A}, \pi_{o f f}$ )

\begin{tabular}{|c|l|l|l|l|l|l|l|l|}
\hline Set of parameters & \multicolumn{1}{l}{$90 / 92$} & $\mathbf{9 2 / 9 3}$ & $\mathbf{9 3 / 9 4}$ & $\mathbf{9 4 / 9 5}$ & $\mathbf{9 5 / 9 6}$ & $\mathbf{9 6 / 9 7}$ & $\mathbf{9 7 / 9 8}$ & $\mathbf{9 8 / 0 1}$ \\
\hline$\left(P L_{L O W}, \hat{Y}_{N A}\right)$ & $-5.5 \%$ & $5.9 \%$ & $-6.4 \%$ & $-24.8 \%$ & $-38.6 \%$ & $-13.0 \%$ & $-36.2 \%$ & $17.8 \%$ \\
\hline$\left(P L_{H I G H}, \hat{Y}_{N A}\right)$ & $-7.1 \%$ & $-1.8 \%$ & $-8.1 \%$ & $-11.9 \%$ & $-17.5 \%$ & $-10.1 \%$ & $-4.7 \%$ & $-2.2 \%$ \\
\hline$\left(P L_{L O W}, \hat{Y}_{S}\right)$ & $0.7 \%$ & $3.3 \%$ & $-9.0 \%$ & $-14.4 \%$ & $-22.4 \%$ & $-10.9 \%$ & $-8.0 \%$ & $-3.1 \%$ \\
\hline$\left(P L_{H I G H}, \hat{Y}_{S}\right)$ & $-2.5 \%$ & $-0.1 \%$ & $-1.8 \%$ & $-9.0 \%$ & $-8.2 \%$ & $-5.2 \%$ & $-5.2 \%$ & $-5.3 \%$ \\
\hline
\end{tabular}

TABLE A7.2

'Growth elasticity of poverty' (Consumption profile given by: $\theta_{N A}, \pi_{o f f}$ )

\begin{tabular}{|c|c|c|c|c|c|c|c|c|}
\hline Set of parameters & $\mathbf{9 0 / 9 2}$ & $\mathbf{9 2 / 9 3}$ & $\mathbf{9 3 / 9 4}$ & $\mathbf{9 4 / 9 5}$ & $\mathbf{9 5 / 9 6}$ & $\mathbf{9 6 / 9 7}$ & $\mathbf{9 7 / 9 8}$ & $\mathbf{9 8 / 0 1}$ \\
\hline$\left(P L_{L O W}, \hat{Y}_{N A}\right)$ & -0.53 & 0.49 & -0.56 & -2.66 & -4.57 & -1.69 & -5.34 & 2.66 \\
\hline$\left(P L_{H I G H}, \hat{Y}_{N A}\right)$ & -0.70 & -0.15 & -0.72 & -1.28 & -2.07 & -1.31 & -0.69 & -0.33 \\
\hline$\left(P L_{L O W}, \hat{Y}_{S}\right)$ & 0.07 & 0.27 & -0.80 & -1.55 & -2.65 & -1.41 & -1.18 & -0.47 \\
\hline$\left(P L_{H I G H}, \hat{Y}_{S}\right)$ & -0.46 & -0.17 & -0.11 & -0.85 & -0.65 & -0.60 & -0.53 & -0.66 \\
\hline
\end{tabular}

TABLE A7.3

Average annual $\%$ change in headcount ratios (Consumption profile given by: $\theta_{S}, \pi_{a d j}$ )

\begin{tabular}{|c|c|c|c|c|c|c|c|c|}
\hline Set of parameters & $\mathbf{9 0 / 9 2}$ & $\mathbf{9 2 / 9 3}$ & $\mathbf{9 3 / 9 4}$ & $\mathbf{9 4 / 9 5}$ & $\mathbf{9 5 / 9 6}$ & $\mathbf{9 6 / 9 7}$ & $\mathbf{9 7 / 9 8}$ & $\mathbf{9 8 / 0 1}$ \\
\hline$\left(P L_{L O W}, \hat{Y}_{N A}\right)$ & $\mathrm{n} / \mathrm{a}$ & $\mathrm{n} / \mathrm{a}$ & $\mathrm{n} / \mathrm{a}$ & $\mathrm{n} / \mathrm{a}$ & $\mathrm{n} / \mathrm{a}$ & $\mathrm{n} / \mathrm{a}$ & $\mathrm{n} / \mathrm{a}$ & $\mathrm{n} / \mathrm{a}$ \\
\hline$\left(P L_{L O W}, \hat{Y}_{S}\right)$ & $\mathrm{n} / \mathrm{a}$ & $-3.5 \%$ & $-14.9 \%$ & $-8.4 \%$ & $-38.8 \%$ & $-28.0 \%$ & $-40.3 \%$ & $-2.6 \%$ \\
\hline$\left(P L_{H I G H}, \hat{Y}_{N A}\right)$ & $\mathrm{n} / \mathrm{a}$ & $-12.8 \%$ & $-12.0 \%$ & $-3.7 \%$ & $-29.5 \%$ & $-23.6 \%$ & $-26.2 \%$ & $-0.5 \%$ \\
\hline$\left(P L_{H I G H}, \hat{Y}_{S}\right)$ & $\mathrm{n} / \mathrm{a}$ & $-5.8 \%$ & $-7.2 \%$ & $-5.2 \%$ & $-12.5 \%$ & $-11.6 \%$ & $-9.1 \%$ & $-8.3 \%$ \\
\hline
\end{tabular}

TABLE A7.4

'Growth elasticity of poverty' (Consumption profile given by: $\theta_{S}, \pi_{a d j}$ )

\begin{tabular}{|c|c|c|c|c|c|c|c|c|}
\hline Set of parameters & $\mathbf{9 0 / 9 2}$ & $\mathbf{9 2 / 9 3}$ & $\mathbf{9 3 / 9 4}$ & $\mathbf{9 4 / 9 5}$ & $\mathbf{9 5 / 9 6}$ & $\mathbf{9 6 / 9 7}$ & $\mathbf{9 7 / 9 8}$ & $\mathbf{9 8 / 0 1}$ \\
\hline$\left(P L_{L O W}, \hat{Y}_{N A}\right)$ & $\mathrm{n} / \mathrm{a}$ & $\mathrm{n} / \mathrm{a}$ & $\mathrm{n} / \mathrm{a}$ & $\mathrm{n} / \mathrm{a}$ & $\mathrm{n} / \mathrm{a}$ & $\mathrm{n} / \mathrm{a}$ & $\mathrm{n} / \mathrm{a}$ & $\mathrm{n} / \mathrm{a}$ \\
\hline$\left(P L_{L O W}, \hat{Y}_{S}\right)$ & $\mathrm{n} / \mathrm{a}$ & -0.28 & -1.31 & -0.91 & -4.59 & -3.63 & -5.95 & -0.38 \\
\hline$\left(P L_{H I G H}, \hat{Y}_{N A}\right)$ & $\mathrm{n} / \mathrm{a}$ & -1.05 & -1.05 & -0.40 & -3.49 & -3.07 & -3.87 & -0.08 \\
\hline$\left(P L_{H I G H}, \hat{Y}_{S}\right)$ & $\mathrm{n} / \mathrm{a}$ & -0.48 & -0.64 & -0.56 & -1.48 & -1.51 & -1.34 & -1.25 \\
\hline
\end{tabular}




\section{NOTES}

1. Recently, Chen and Ravallion (2004) (henceforth, CR) presented, based on their work at the World Bank using the '\$1 per day' poverty concept, a set of poverty estimates that attempts to be comprehensive in terms of time span and coverage of countries. They concluded that between 1981 and 2001, the $\$ 1 /$ day poverty headcount (as a share of the developing world population) fell by half if China is included in the analysis (from 40.4 percent to 21.1 percent). However, when China's performance is not accounted for, the reduction in the poverty headcount ratio was from 31.7 percent to 22.5 percent (see Table 1.1. in Appendix 1). Furthermore, the absolute number of ' $\$ 1$ per day' poor rose slightly outside of China, from 848.1 million in 1981 to 877.4 million in 2001.

2. As Khan and Riskin (2001) note (p. 63), "...income, rather than expenditure, is the variable in terms of which the poverty threshold is defined. It has been argued that expenditure is a better measure of 'permanent income' than is current income. A discussion of the validity or otherwise of this argument is operationally irrelevant because distributional data in China are available only for income."

3. The program and documentation are available on <http://www.worldbank.org/research/povmonitor/software.htm>.

4. The cited motivation is puzzling since a poverty line ought to be used to assess rather than reflect living standards.

5. The authors use poverty lines published, beginning in 1997, in the China Development Report for more than 300 cities.

6. The language used in the paper suggests that this threshold is based on a nutritional standard, but it is not clearly defined.

7. Source: WB Global Poverty Monitoring <http://www.worldbank.org/research/povmonitor/PPP1993.htm> (accessed: October 22, 2003). The income shares are from the Chinese National Statistical Bureau and are based on the China Rural/Urban Household Surveys conducted in the respective years (with the exception of the data for 1996, 1997 and 2001, for which the data sources were not listed on the website). These national income shares are based on pooling of urban and rural surveys (after inter-sectoral price adjustments).

8. Actually, \$1.08/day (see Chen and Ravallion, 2001a).

9. All poverty lines in this table have been expressed in 1993 prices using the rural, urban or national official CPI, as appropriate.

10. A separate issue (from that of price adjustments) that might be raised concerns differences in the commodities required to achieve the same basic requirements (such as nutritional adequacy) in different provinces or sectors. This is certainly an issue that should ultimately be taken up in a credible poverty estimation exercise for China but goes well beyond the scope of the existing literature.

11. See Appendix 4.

12. A figure of around seven percent was documented by Chen and Ravallion (2001a, p. 7).

13. The finding that survey-based household mean incomes have grown only slightly less than official per capita GDP figures is relevant to the debate on whether China's GDP growth rates are overstated (see, for example, Rawski 2002). The small difference between the national accounts and survey-based average growth rates of income suggests that the amount by which China's economic growth rates during the 1990s might have been overstated is not likely to have been as substantial as argued by some analysts.

14. In this analysis, we are accommodating the view that the national accounts provide a plausible estimate of per capita private income -- without endorsing this approach. We wish to include this approach among those we consider in our sensitivity analysis since it has been widely employed in the recent literature (see Bhalla 2002, Sala-i-Martin 2002a, 2002b, 2006), notwithstanding damning critiques such as those by Sundaram and Tendulkar (2001), Havinga and Kamanou (2003) and Deaton (2005).

15. We discuss the construction of the income variables from the 1995 surveys in Appendix 5a. Furthermore, a detailed description of the consumption measure used as well as the decile-specific C/I ratios is given in Appendix $5 \mathrm{~b}$.

16. In particular, the official Chinese CPI reflects weights based on an overall average consumption pattern (wherein food accounts for only approximately one third of expenses in the average basket of goods, while expenditures on entertainment, education, culture, transportation and communication for one fifth) (see e.g., Singapore Department of Statistics, 2001). This method renders it not especially appropriate for assessments of the costs of avoiding the most absolute forms of poverty.

17. The first-best consumer price index to apply would be that corresponding to the cost of poverty avoidance in China, but this is unknown since it cannot be specified without first fully defining a criterion for identifying the poor (on the basis of which the cost of poverty avoidance might be determined). Thus, the consumer price index we apply is a makeshift alternative.

18. Khan and Riskin (2001) also construct adjusted price indices to better reflect living costs faced by individuals at or near the poverty line. They find that whereas the use of the official CPI leads to an apparent fall in urban poverty between 1988 and 1995, the substitution of an adjusted CPI leads to an apparent increase. A direct comparison between their results and ours is not possible for a number of reasons: we analyze Chinese national poverty whereas they disaggregate the analysis at the urban and rural level, using distinct poverty lines for each sector. Our adjusted CPI is different from theirs, and our comparison of poverty in different years is conducted over a distinct time period.

19. For a detailed description of the reforms, see, for example, Cheng (1996).

20 According to the revised GDP data, the average annual GDP growth rate between 1993 and 2001 is higher by 1.4 percentage points as compared to the earlier reported GDP growth rate. Furthermore, the revised GDP is higher than the earlier reported GDP for each year by multiplicative factors monotonically rising from 1.02 in 1993 to 1.13 in 2001. Taking account of this upward revision, therefore, would lead (for those poverty estimates dependent on national accounts 
estimates of per capita income) to the conclusion that (a) the estimated average consumption levels were slightly higher and poverty levels were correspondingly lower than shown in this paper, and (b) poverty reduction rates were higher throughout the period. Due to the relatively small magnitude of the revision, however, we judged that it was not warranted to re-estimate poverty as a consequence of the upward revision of GDP data.

21. The estimates for China's poverty headcount ratio are obtained using income profiles (p. 8, Chen and Ravallion 2004)

22 . Based on the national "lower income line" representing approximately $\$ 1 /$ day at PPP.

23. Based on the national "lower income line" representing approximately $\$ 1 /$ day at PPP.

24. Source: WDI 2003.

25. The results based on the second interpolation method are available from the authors upon request.

26. The income variable is discussed in detail in Appendix 5 a.

27. Poverty estimates based on the Method II PPPs and the corresponding poverty lines are available from the authors upon request.

28. The 2003 China Statistical Yearbook states (p. 340) that survey-based mean income estimates are obtained from annual rural surveys covering 68,000 households and urban surveys covering 40,000 households. Furthermore, it states that "the respondent [urban] households are selected by the two stage stratified systematic random sampling scheme" and respondent rural households are selected by "a combination of various sampling approaches".

29. We used the general official CPI to evaluate national income at constant 1990 prices. Using the separate rural and urban CPIs to express first the rural and urban mean incomes at constant prices, and subsequently obtaining an estimate of the national mean income as a weighted average of the resulting sectoral incomes (with the weights given by rural and urban population shares) does not change the main conclusions. In particular, employing the latter procedure, we find that the average annual growth rate of survey-based per capita income is 7.44 percent between 1990 and 2001 . Furthermore, the average national accounts to survey mean income ratio is 2.07, while the median ratio is 2.12 .

30. The only caveat to this procedure is that we cannot separately identify and subtract the value of produce which is used as input into the production of self-consumed food (for example, corn).

31. Despite this discrepancy, however, the food shares in total expenditure are very similar to those based on the income variable produced with the SAS codes, to which we add RY4. Furthermore, the consumption to income ratios are very similar to those obtained by adding RY4 to the income variable (based on the SAS codes) for the lowest six deciles. Therefore, using the ready-made cash income from sales of agricultural output or the one constructed from scratch would make little difference to poverty estimates. So, we decide to use the former. 
International Poverty Centre SBS - Ed. BNDES, $10^{\circ}$ andar 70076900 Brasilia DF Brazil

povertycentre@undp-povertycentre.org www.undp.org/povertycentre

Telephone +55 6121055000

Fax +55 6121055001 